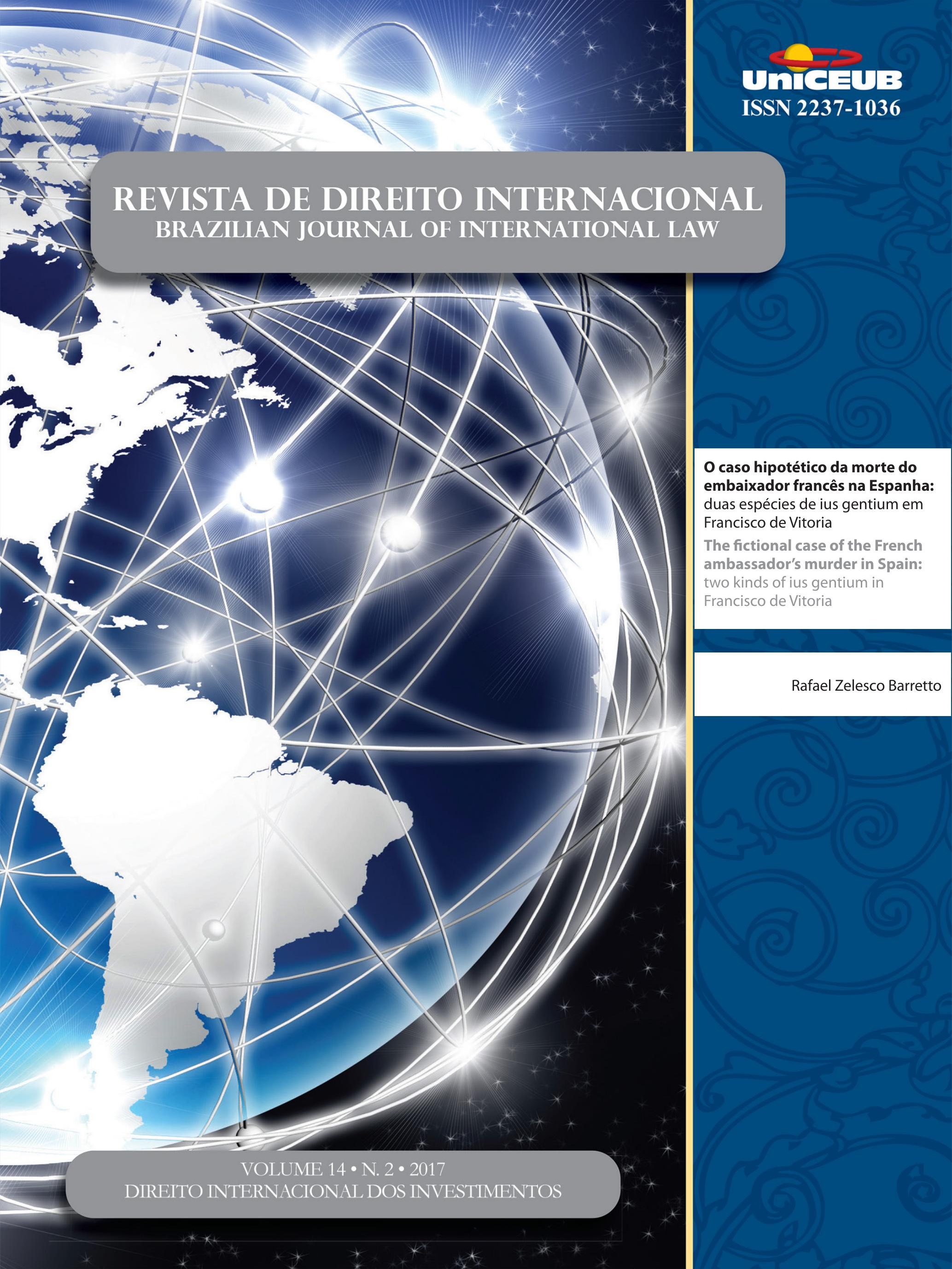




\section{Sumário}

I. Crônicas do Direito Internacional ...............................................1

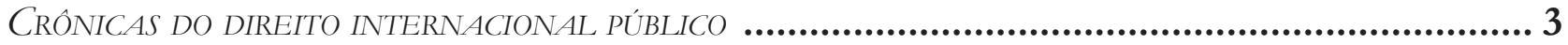

A resolução 2272 (2016) do Conselho de Segurança das Nações Unidas - O POSICIONAMENTO DA ONU FACE ÀS ALEGAÇÕES DE ABUSO E EXPLORAÇÃo SEXUAL POR SUAS

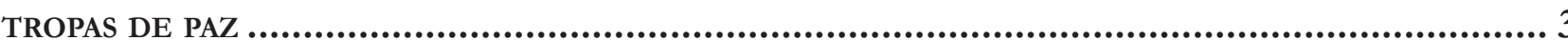

Sarah Dayanna Lacerda Martins Lima

CRÓNICAS DE DiREITo INTERNACIONAL PRIVADO...................................................................

Nadia de Araujo, Marcelo De Nardi, Gustavo Ribeiro, Fabrício Polido e Inez Lopes

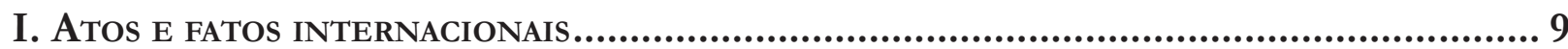

Crônica 1. Novidades de 2017 SObRE CIRCulaÇÃo faCilitada DE SENTENÇAS ESTRANGEIRAS 9

Crônica 2: O Direito Transnacional e os episódios das Carnes.........................................16

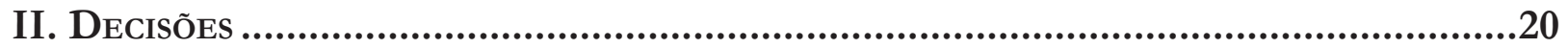

Crônica 3: A Irresistível ForÇa da ORDEM PÚblica E A HOMOLOGaÇÃo DE SENTENÇAS

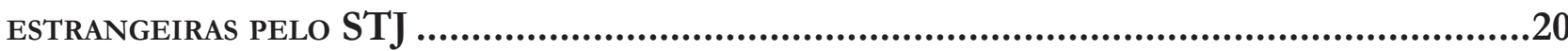

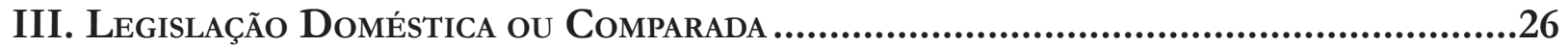

Crônica 4 - Dignidade da pessoa humana e mudança de paradigma da Lei de Migração

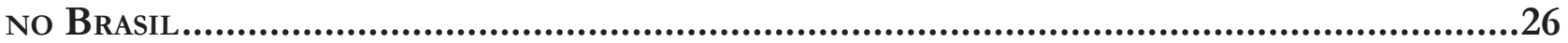

II. Dossiê especial: Direito Internacional dos InVEstimentos ................35

Non-adjudicatory State-State Mechanisms in Investment Dispute Prevention and Dispute Settlement: Joint Interpretations, Filters and Focal Points 
Mapping the Duties of Private Companies in International Investment Law .50 Nitish Monebhurrun

LA LÉGALITÉ DE L'INVESTISSEMENT DEVANT L'ARBITRE INTERNATIONAL: À LA RECHERCHE D'UN POINT D'ÉQUILIBRE .73 Hervé Ascensio

Host STATES AND STATE-STATE INVESTMENT ARBITRATION: STRATEGIES AND CHALlENGES......81 Murilo Otávio Lubamdo de Melo

Right to Regulate, Margin of Appreciation and Proportionality: Current Status in Investment Arbitration in Light of Philip Morris V. Uruguay. .95 Giovanni Zarra

Investments on Disputed Territory: Indispensable Parties and Indispensable Issues....122 Peter Tzeng

The Influence of General Exceptions on the Interpretation of National

Treatment in INTERNATIONAL INVESTMENT LAW. 140 Louis-Marie Chauvel

UMA PRoposta de REFleXão SObRe os ACFIs: Até QUE PONTO O TRATAMENTo de NAÇão MAIS FAVORECIDA PODE MINAR A ESTRATÉGIA POLÍTICA QUE OS EMBASA? 160

Michelle Ratton Sanchez Badin, Daniel Tavela Luis e Mario Alfredo de Oliveira

ECUADOR's 2017 TERMINATION OF TREATIES: HOW NOT TO EXIT THE INTERNATIONAL INVESTMENT REGIME 179

Jose Gustavo Prieto Muñoz

ONE BELT, ONE ROAD: NOVAS INTERFACES ENTRE O COMÉRCIO E OS INVESTIMENTOS INTERNACIONAIS 193

Flávio Marcelo Rodrigues Bruno e Marilda Rosado de Sá Ribeiro

III. Artigos Sobre outros TEMAS..................................................... 214

TolerânCIA E REFugIO: UM ENSAIO A PARTIR Do ACORdo EU-TurQUiA 216 Flávia Cristina Piovesan e Ana Carolina Lopes Olsen 
O TRATAMENTO do APÁtridA NA NOVA LEI DE MIGRAÇÃo: ENTRE AVANÇOS E RETROCESSOS...237 Jahyr-Philippe Bichara

O caráter humanista da Lei de Migrações: aVAnços da Lei N. 13.445/2017 E Os desafios DA REGULAMENTAÇÃO. 254 Marcelo Dias Varella, Clarice G. Oliveira, Mariana S.C. Oliveira e Adriana P. Ligiero

Reform of the United Nations Security Council: The Emperor Has No Clothes.268 Ljubo Runjic

A IDEIA DE QUe os LATINO-AMERICANOS PREFEREM O AUTORITARISMO À DEMOCRACIA À luz da reinterpretação dos Critérios do Programa das Nações Unidas para o DesenVolvimento 286

Gina Marcilio Pompeu e Ana Araújo Ximenes Teixeira

A PRoteção da ORIENTAÇÃo SEXUAL E IDENTIDAdE DE GÊNERO DIVERSAS NA CORTE PENAL internacional: Entre Realpolitiks E Os Direitos Humanos

Gustavo Bussmann Ferreira

A desnacionalização e as violações de direitos humanos na República Dominicana. 331 Daniela Menengoti Gonçalves Ribeiro e Rodrigo Ichikawa Claro Silva

CompetênCia do TPI no Caso do ATAque ao hospital de Kunduz: uma análise ENVOLVENDO A JURISDiÇÃo do TPI EM RELAÇÃO A NACIONAIS DE EsTAdOS NÃO-PARTE do Estatuto DE Roma

Filipe Augusto Silva e Renata Mantovani de Lima

A CRIMINALIZAÇÃo DOS IMIGRANTES EM SITUAÇÃo IRREGULAR NA ITÁliA: BIOPOLÍtica E DIREITO PENAL DO AUTOR.

Maiquel Angelo Dezordi Wermuth e Jeannine Tonetto de Aguiar

The New Rules On Trade And Environment Linkage In Preferential Trade Agreements

Alberto do Amaral Júnior e Alebe Linhares Mesquita

Beyond THE Border between the North and the South: towards a Decolonization of EPISTEMOLOGIES AND FIELDS OF RESEARCH ON MERCOSUR 
A aplicabilidade da Convenção de Montreal no direito brasileiro.

Aziz Tuffi Saliba e Alexandre Rodrigues de Souza

REgIME DE TRANSPARÊNCIA FISCAL NA TRIBUTAÇÃo DOS LUCROS AUFERIDOS NO EXTERIOR (CFC RULES): LACUNAS E CONFLITOS NO DIREITO BRASILEIRO

Paulo Rosenblatt e Rodrigo Torres Pimenta Cabral

As Regras Brasileiras de Tributação de Controladas e Coligadas no Exterior: verdadeiras Controlled Foreign Company (CFC) Rules? .......................................465

Melina de Souza Rocha Lukic e Amanda Almeida Muniz

O RETORNO DE BENS CULTURAIS

Aziz Saliba e Alice Lopes Fabris

Direitos culturais e Nações Unidas: uma análise a partir da Declaração Sobre a eliminação de Todas as Formas de Intolerância e Discriminação Baseadas na Religião OU NA CRENÇA

Leilane Serratine Grubba e Márcio Ricardo Staffen

OS REFLEXOS DA PROTEÇÃO INTERNACIONAL DA PROPRIEDADE INTELECTUAL PARA O DESENVOLVIMENTO INTERNO: UMA ANÁLISE SOBRE O SISTEMA PATENTÁRIO BRASILEIRO E A TRANSFERÊNCIA DE TECNOLOGIA

Michele M. Segala e Isabel Christine S. De Gregori

O CASO HIPOTÉTICO DA MORTE DO EMBAIXADOR FRANCÊS NA ESPANHA: DUAS ESPÉCIES DE IUS gentium em Francisco de Vitoria

Rafael Zelesco Barretto

De volta À BeVilaqua: anÁlise ECONÔMICA dA APLICAÇão do ART. $9^{\circ}$ DA LINDB Às OBRIGAÇÕES CIVIS CONTRATUAIS

Danielle Cristina Lanius e Ivo Teixeira Gico Jr 


\title{
O caso hipotético da morte do embaixador francês na Espanha: duas espécies de ius gentium em Francisco de Vitoria*
}

\author{
The fictional case of the French ambassador's \\ murder in Spain: two kinds of ius gentium in \\ Francisco de Vitoria
}

Rafael Zelesco Barretto**

\section{Resumo}

O artigo expõe uma parte pouco comentada do pensamento de Francisco de Vitoria, a quem se costuma atribuir papel importante no desenvolvimento da ciência do Direito Internacional. Em seus comentários à Suma Teológica de Tomás de Aquino, Vitoria propôs um caso hipotético para ilustrar a obrigatoriedade do direito das gentes. Narrou o suposto assassinato do embaixador francês na Espanha, afirmando que tal conduta seria injusta por violar o ius gentium. Tal reprovabilidade foi justificada em dois níveis, que Vitoria relacionou a duas espécies de direito das gentes. O primeiro destes seria geral e decorreria de um consentimento virtual de todo o universo, enquanto que o segundo seria específico e resultaria do acordo entre algumas nações. A distinção é feita de passagem e o mestre salmantino não a desenvolve. Nas páginas a seguir, argumenta-se que a dualidade no direito das gentes é uma marca distintiva do pensamento vitoriano. Assim, expõem-se outras passagens da obra do dominicano nas quais a distinção mencionada reaparece perante casos concretos. Para efeitos de comparação, o artigo também descreve e responde a interpretações diferentes, feitas por outros estudiosos de Vitoria. Conclui-se que a dualidade no ius gentium contribui para aproximá-lo do direito natural, indicando-lhe uma finalidade e controlando os excessos do voluntarismo estatal.

Palavras chave: Direito das gentes. Segunda Escolástica. Direito natural.

* Recebido em 21/01/2017

Aprovado em 11/07/2017

** Doutor e Mestre em Direito Internacional pela Universidade do Estado do Rio de Janeiro (UERJ). Professor dos cursos de Direito e de Relações Internacionais do Centro Universitário Lasalle do Rio de Janeiro (Niterói-RJ). Email: rafaelzb2010@gmail.com.

\section{Abstract}

This paper presents a less commented part of the teachings of Francisco de Vitoria, to whom it is nowadays usual to attribute a major role in the development of international law theory. In his commentaries on Thomas Aquinas' Summa Theologica, Vitoria draws on a hypothetical case in order to explain the obligatory nature of ius gentium. He told a fictional story about the murder of the French ambassador to Spain, claiming such an act would be unjust since it violated ius gentium. Vitoria then elaborates on the reproachable character of that homicide, by means of a twofold reasoning, related to two different kinds of ius gentium. The first is general 
and established by a virtual consent of the whole universe, while the second is more specific and roots in agreement between some nations only. This distinction is drawn incidentally and without further developments. This essay argues that the dual character of ius gentium is a distinctive feature of Vitoria's thought. In this sense, other passages of the dominican's work show this differentiation while handling concrete situations. Further, the article draws a comparison and provides answers to different positions of other experts on Vitoria. The conclusion is that duality in Vitoria's law of nations brings it nearer to natural law, gives ius gentium a finality and controls the excesses of state voluntarism.

Keywords: Ius gentium. Second Scholasticism. Natural law.

\section{INTRODUÇÃO}

Este artigo examina a noção de ius gentium nos comentários de Francisco de Vitoria à questão 57 ("O Direito”) da Secunda Secundae da Suma Teológica. Trata-se de salientar um aspecto que parece ser pouco comentado entre os estudiosos do pensamento vitoriano, qual seja, a divisão que o mestre salmantino opera dentro do conceito de direito das gentes, ali distinguindo uma espécie oriunda de um pacto público e outra provinda de um acerto privado. A menção a este caráter dual do direito das gentes é breve e um tanto confusa. O problema é discutido pelo teólogo através de um exemplo fictício - a morte do enviado francês mencionada no título deste artigo - que, contudo, não cumpre exatamente sua finalidade, em parte devido ao hábito escolástico de exagerar na exposição de argumentos favoráveis. Deve ser dito também que Vitoria não retoma esta tese explicitamente nas suas famosas Relectiones sobre os índios e o direito da guerra. Contudo, este trabalho buscará evidenciar que a distinção apontada é fundamental para compreender a natureza do ius gentium vitoriano, bem como suas controversas relações com o ius naturale e o ius civile. Em última análise, argumentar-se-á que uma das causas - se não a principal - da vitalidade da doutrina de Francisco de Vitoria está na delicada relação que ele estabelece, desenvolvendo o pensamento de Tomás de Aquino, entre as duas espécies de direito das gentes.

Para tanto, seguir-se-á esta ordem: a próxima seção trará uma breve síntese da lição vitoriana sobre o artigo $3^{\circ}$ da quaestio 57 do Tratado sobre a Justiça de Santo Tomás, destacando-se as dúvidas sobre a essência, natural ou positiva, do ius gentium, sobre sua obrigatoriedade e sobre os atores que estarão eventualmente vinculados ao mesmo. O capítulo seguinte estará centrado na hipótese do assassinato do embaixador francês na Espanha, perante a qual se intentará pôr em evidência a bipartição do direito das gentes feita por Vitoria. Sucessivamente, alguns esquemas interpretativos rivais serão passados em revista. Outro tópico buscará comprovar a tese aqui defendida cotejando diversas passagens das obras do dominicano burgalês. Por fim, espera-se concluir esclarecendo qual o lugar do direito das gentes no pensamento jurídico de Francisco de Vitoria, bem como reavaliando seu aporte ao debate atual sobre o direito internacional.

\section{SínteSE DA DOUTRINA Vitoriana do DiREITO DAS GENTES}

Seguindo o roteiro traçado pelo Aquinate, Francisco de Vitoria se depara com o direito das gentes ao estudar a divisão do direito. Dois posicionamentos tradicionais se opunham desde a Idade Média, o primeiro sustentando uma divisão dual ${ }^{1}$, o outro advogando pela tripartição ${ }^{2}$. O direito das gentes constituía o pomo da discórdia, pois as duas correntes concordavam em re-

1 Sua origem mais visível estava no jurisconsulto Gaio: "Todos os povos que são regidos por leis e costumes usam um direito que, em parte, lhes é próprio e, em parte, é comum a todos os homens, pois o direito que cada povo promulga para si mesmo esse lhe é próprio e se chama direito civil, direito inerente à própria cidade, mas o direito que a razão natural constituiu entre todos os homens e entre todos os povos que o observam, chama-se direito das gentes, como se disséssemos o direito que todos os povos usam. Assim, também, o povo romano usa de um direito que, em parte, lhe é próprio e, em parte, comum a todos os homens." GAIUS. Institutas do Jurisconsulto Gaio. Tradução de J. Cretella Jr. e Agnes Cretella. São Paulo: Revista dos Tribunais, 2004, 1,1. Também Aristóteles poderia ser incluído aqui, por não mencionar um ius gentium. ARISTÓTELES, Ética a Nicômaco. Tradução de António de Castro Caeiro. São Paulo: Atlas, 2009, 1134b.

2 Com base no jurisconsulto Ulpiano: "O direito privado é tripartido: foi, pois, selecionado ou de preceitos naturais, ou civis, ou das gentes." AA.VV. Digesto de Justiniano. Liber Primus. Introdução ao Direito Romano. Tradução de Hélcio Maciel França Madeira. $3^{a}$ ed. São Paulo: Revista dos Tribunais. Osasco: UNIFIEO, 2002, D.1.1.1.2. Também: "O direito das gentes é aquele do qual os povos humanos se utilizam. O que permite facilmente entender que ele se distancia do natural, porque este é comum a todos os animais e aquele é comum somente aos homens entre si." Idem, D.1.1.1.4 
lação à existência dos direitos natural e civil. É bom ter em mente que não se tratava de uma discussão sobre a divisão didática dos ramos do direito, como quando se discute hoje se o direito do trabalho ou o direito internacional privado integram o direito público ou privado. $\mathrm{O}$ quid referia-se à determinação das fontes do direito, isto é, a qual tipo de raciocínio se deveria recorrer para conhecer o que seria justo em cada circunstância ${ }^{3}$.

Mantendo-se na tradição cristã que remontava a Santo Isidoro de Sevilha, Tomás de Aquino segue Ulpiano na tripartição, embora divirja do romano em relação à definição de direito natural, por só admitir aplicá-lo de modo impróprio e por extensão aos animais irracionais ${ }^{4}$. Contudo, a questão era mais complicada do que parecia, pois os conceitos de direito natural e direito civil opunham-se diretamente em alguns aspectos, tertium non datur. A pergunta sobre a origem do direito deixa isto bem claro: existe o justo que procede da vontade humana, e existe aquele que não. No primeiro caso, tem-se o direito civil, humano ou positivo ${ }^{5}$, no segundo, ingressa-se no direito natural. E quanto ao direito das gentes? Deverá por força inserir-se em alguma destas opções. O mesmo problema teórico se apresenta ao discutir a obrigatoriedade do direito: esta pode residir na adequação à natureza do homem ou em um mandato instituído por uma autoridade. Difícil conceber uma opção fora destas, que fosse reservada ao ius gentium.

Assim, o problema do enquadramento do direito dos povos era comum aos partidários das duas correntes. Aqueles que advogavam por duas espécies básicas de direito precisavam assimilar o ius gentium a algum dos outros tipos. E os que propunham sua autonomia deviam, não obstante, decidir-se a aproximá-lo do ius civile ou do naturale na resposta às questões fundamentais expostas acima.

É sabido que Santo Tomás vacila perante este problema, concedendo neste passo e no Tratado sobre a

3 VILLEY, Michel. A formação do pensamento jurídico moderno. São Paulo: Martins Fontes, 2005, pags. 47-65.

4 Ao conceituar lei natural, o Aquinate faz referência às inclinações que o homem possui em comum com os demais animais (AQUINO, Santo Tomás de. Suma de Teología, vol. 2, 2ª ed. Madri: BAC, 1989, I-II q. 94 a.2, onde cita Ulpiano). Porém sua intenção não parece ser a de incluir os animais entre os sujeitos do direito natural, como fica claro ao tratar da licitude de matar os demais seres vivos quando isto for necessário para o homem (AQUINO, Santo Tomás de. Suma de Teología, vol. 3. Madri: BAC, 1990, II-II q. 64 a.1 ad 2).

5 Frequentemente empregados como sinônimos, sem embargo das conotações bastante diferentes que adquirirão posteriormente.
Lei $^{6}$ respostas que, embora mantenham uma coerência de fundo ${ }^{7}$, efetivamente divergem na ênfase dada a um ou outro direito em sua ligação com o ius gentium ${ }^{8}$.

Francisco de Vitoria mantém a divisão tripartite. Notando a dificuldade enfrentada pelo Doutor Angélico, reserva seu comentário sobre o problema exclusivamente para o Tratado sobre a Justiça, evitando cair em contradição. Na questão 57, principia distinguindo, na esteira do autor da Suma, o direito das gentes do direito natural: este compreende aquilo que é adequado a outrem em razão da igualdade, como por exemplo a devolução de um empréstimo. Caso a quantia tomada não seja restituída, o devedor estará assumindo uma posição superior ao credor, pois beneficiou-se com o prejuízo do outro. A devolução é de direito natural por uma exigência básica de igualdade - ou, como formula Vitoria, "por si mesmo diz igualdade e justiça". Já o direito das gentes refere-se àquilo que é adequado ao outro a partir de um critério distinto da mera exigência de igualdade. Trata-se de um direito mais sofisticado: a proporcionalidade da conduta será medida por algum outro parâmetro valioso. Vitoria usa o mesmo exemplo que Santo Tomás: o caráter privado da propriedade não é uma consequência da simples igualdade entre os homens. Na verdade, sua legitimidade decorre de uma avaliação adicional. Se os bens não estivessem repartidos, seguir-se-iam intermináveis disputas pela posse. Logo, em atenção à paz e concórdia entre os homens (critério adicional), que possibilita manter a igualdade básica entre todos (primeiro critério da justiça), a instituição da propriedade privada deve reputar-se justa. Trata-se de uma exigência do ius gentium.

Separado o direito dos povos do ius naturale, é preciso resguardar-se para não tombar no extremo oposto. Surge aí a tormentosa questão sobre a natureza do ius gentium. O fato de não identificar-se plenamente com o direito natural já basta para adscrevê-lo ao ius positivum?

6 AQUINO, Santo Tomás de. Suma de Teología, vol. 2, $2^{\text {a }}$ ed. Madri: BAC, 1989, I-II q.95 a.4.

7 HERRERA, Daniel Alejandro. Ius gentium: ¿derecho natural o positivo? In: IDOYA ZORROZA, María (org.). Proyecciones sistemáticas e históricas de la teoría suareciana de la ley. Col. "Cuadernos de pensamento español", n 37. Pamplona: Universidad de Navarra, 2009, pag. 49.

8 Comentando a I-II q. 95 a.4, Francisco de Vitoria nota que "na II-II q. 57 [...] [Tomás] diz o contrário do que fala neste artigo". VITORIA, Francisco de. La ley. Tradução de Luis Frayle Delgado. $2^{a}$ ed. Madri: Tecnos, 2009, pag. 36.

9 VITORIA, Francisco de. La justicia. Tradução e introdução de Luis Frayle Delgado. Madri: Tecnos, 2003, pag. 23. 
Vitoria continua com Santo Tomás: o direito das gentes assemelha-se mais ao direito civil que ao natural. Ele reconhece que muitos, especialmente entre os juristas, preferiam aproximar o direito das gentes do direito natural, em deferência aos romanos da época tardia, cujo ius gentium era fortemente influenciado pelo estoicismo. Contudo, não se deixa seduzir: após manifestar um certo enfado com a persistência desta discussão - " digo en primer lugar que la discusión es más bien acerca del nombre que de la realidad, pues interesa poco decir una u outra cosa" ${ }^{10}$ - afirma claramente que o direito das gentes deve ser incluído no direito positivo:

Decimos, pues, con Santo Tomás, que el derecho natural es un bien por si mismo, sin orden alguno a otro. En cambio, el derecho de gentes no es un bien de suyo, esto es, se dice que el derecho de gentes no tiene en si equidad por su propia naturaleza, sino que está sancionado por un consenso de los hombres. $Y$ asi respondo a la cuestión principal con esta conclusión: que el derecho de gentes más bien debe ponerse dentro del derecho positivo, que del natural. ${ }^{11}$

Como se vê, o motivo principal para a decisão de Vitoria pelo direito positivo é o consenso dos homens que está por trás do ius gentium. Uma vez que este é produto do consentimento dos vários povos e nações ${ }^{12}$, obedece à racionalidade do direito civil, e não tanto aos ditames pré-voluntários do ius naturale.

Situando o direito das gentes no direito positivo, o teólogo burgalês se vê diante de um novo problema: a lei positiva obriga somente aqueles que a ela aderiram. Em uma conferência anterior (Relectio de Potestate Civii), ele havia formulado uma teoria da translação, pela qual o poder civil, provindo de Deus, era trasladado à comunidade humana, que em seguida, por razões de conveniência e prudência, o atribuía a um soberano ${ }^{13}$. Ora, se o poder residia, então, na comunidade humana como um todo, e se o poder do governante se devia unicamente ao consentimento da comunidade (ain-

10 VITORIA, Francisco de. La justicia. Tradução e introdução de Luis Frayle Delgado. Madri: Tecnos, 2003, pag. 25.

11 VITORIA, Francisco de. La justicia. Tradução e introdução de Luis Frayle Delgado. Madri: Tecnos, 2003, pag. 26.

12 Neste trabalho, os conceitos de "povo", "nação", "república" e "Estado" serão utilizados indistintamente, entendendo-se que não há sentido, para os fins buscados aqui, em aplicar-lhes as distinções que a ciência política desenvolveu nos séculos posteriores a Francisco de Vitoria. Seu sentido será o de "comunidade autônoma" ou "perfeita", no dizer do mestre salmantino.

13 VITORIA, Francisco de. Relectio de Potestate Civili. Estudios sobre su Filosofía Política. Edição crítica de Jesús Cordero Pando. Col. "Corpus Hispanorum de Pace", segunda série, vol. 15. Madri: CSIC, 2008, pags. 21-27. da que tal consentimento fosse dado uma vez apenas e já considerado suficiente inclusive para as gerações seguintes), como justificar a obrigatoriedade do ius gentium, se este direito não fora especificamente promulgado por nenhum soberano investido do poder civil por seus súditos? Em outras palavras, como diz Vitoria, "si el derecho de gentes fuera de derecho positivo, como se ha dicho, y no de derecho natural, el problema estaría en si el violar el derecho de gentes es pecado". Fazendo uma adaptação ao século presente, quando o dominicano diz "pecado", pode-se entender "ilícito grave". Vitoria prossegue com seu questionamento: Ainda admitindo-se que alguns povos consentiram com o direito das gentes, como justificar sua obrigatoriedade para aqueles que deliberada e constantemente se mantém longe dele?

Portanto, a primeira resposta de Vitoria - o direito das gentes é direito positivo - levanta uma nova questão. Se o ius positivum está baseado no consentimento da república, como justificar a obrigatoriedade do direito das gentes, em especial naqueles casos em que toda a república obra conscientemente de modo contrário aos preceitos deste direito dos povos?

\section{A duplicidade do IUS Gentium em Vitoria}

Fiel ao método escolástico, Francisco de Vitoria responde a estas dúvidas com uma distinção: o direito das gentes é duplo, analogamente à duplicidade do direito positivo. Com efeito, ao tratar deste, na lição anterior, o regente de Prima dizia que correspondia ao que era justo por determinação tanto de uma lei quanto de um pacto privado. Acrescentava que a lei também podia ser considerada um pacto público, e assim todo o direito positivo tinha origem no consenso humano ${ }^{14}$. Ora, da mesma forma que o direito positivo possuía origem dupla, em pacto público ou privado, também o ius gentium exibiria tal complexidade: "bemos sostenido que es doble el derecho de gentes, lo mismo que es doble el derecho positivo, como hemos dicho antes" 15 .

O mestre salmantino prossegue explicitando o paralelismo, pois o direito dos povos também poderia ter sua origem em um pacto público ou um privado. Inten-

14 VITORIA, Francisco de. La justicia. Tradução e introdução de Luis Frayle Delgado. Madri: Tecnos, 2003, pag. 14.

15 VITORIA, Francisco de. La justicia. Tradução e introdução de Luis Frayle Delgado. Madri: Tecnos, 2003, pag. 27. 
ta esclarecer a questão com o exemplo do embaixador francês:

$$
\begin{aligned}
& \text { Supongamos, por ejemplo, que nosotros tengamos guerra con } \\
& \text { los franceses y los franceses envíen un embajador, al que los } \\
& \text { españoles dan muerte contra el derecho de gentes. ¿Por qué } \\
& \text { y cómo sabéis vosotros que no (nosotros) hayamos admitido } \\
& \text { aquel derecho de gentes y que hayamos pecado matando al } \\
& \text { enemigo? }{ }^{16}
\end{aligned}
$$

A questão é bastante gráfica: sob qual fundamento uma nação poderia exigir que algum preceito do direito das gentes fosse respeitado por outra parte? Caso os espanhóis executassem o legado francês, como provar que os ibéricos haviam violado uma norma de direito? Estes últimos não poderiam alegar que não haviam admitido tal costume e que, portanto, não se encontravam vinculados ao mesmo? Em última análise: qual o motivo para afirmar que os diferentes povos e nações estariam obrigados pelo ius gentium?

Vitoria explica que o direito das gentes pode originar-se de um consenso comum ou de um acordo particular. No caso da imunidade dos enviados diplomáticos, esta é observada em toda parte por força do ius gentium público, que vigora entre todas as nações e é universalmente respeitado. Não se trata de justificar a vigência desta norma pelo mero fato de ser um costume universal. É precisamente o contrário: a manutenção de embaixadas e do relacionamento interestatal daí decorrente é um importante fator na prevenção das guerras. Para que possam conviver, os povos necessitam um convívio civilizado, e os legados têm a importante função de possibilitar a conversação e a troca de opiniões entre os países. Tais funcionários não poderiam exercer bem seu papel, porém, caso não fossem invioláveis na república perante a qual representassem seu governo. Daí dizer-se que a proteção aos embaixadores decorre do direito das gentes público - primeiro ius gentium vitoriano.

Ocorre que nem todas as normas do direito das gentes possuem valor universal. O teólogo burgalês propõe a questão:

16 VITORIA, Francisco de. La justicia. Tradução e introdução de Luis Frayle Delgado. Madri: Tecnos, 2003, pag. 27. Nota do tradutor da versão espanhola, aqui em tradução livre: "No texto original existem duas versões latinas, non (não) e nos (nós). A última nos parece mais conveniente ao contexto." A respeito, pode-se dizer que, no contexto da citação, a diferença é pouco relevante, uma vez que o cerne da questão está exatamente em saber se "aquel derecho de gentes" obrigava ou não os espanhóis. Portanto, é indiferente que a dúvida seja acerca de se os espanhóis admitiram aquele costume, ou de se não o admitiram.
El problema está en si es pecado violar el derecho de gentes que aún no ha sido sancionado para algunos; es decir, la duda está al hablar del derecho de gentes no escrito, o también del escrito que no obliga a todos los hombres del mundo, como está claro tratándose de la muerte de los embajadores, que va contra el derecho de gentes. No todos están obligados a observar el derecho de gentes, puesto que no es natural. ${ }^{17}$

O assunto se complica: há um direito das gentes que não vincula todas as pessoas ou povos, por não ter sido sancionado para todos. Em outras palavras, a universalidade não é característica essencial do ius gentium, podendo estar ou não presente, sem que isto altere a natureza e a juridicidade de tais normas. Surge aqui o segundo direito das gentes vitoriano, oriundo de um consentimento restrito a algumas nações.

O exemplo dos embaixadores retorna aqui, e o mestre salmantino parece enredar-se na discussão. Ele não acabara de dizer que a imunidade diplomática era exigência do ius gentium universal?

$\mathrm{Na}$ verdade, é bom lembrar aqui do hábito escolástico de, perante alguma discussão acadêmica, empilhar argumentos em prol e contra cada posição, esmerando-se particularmente, sem dúvida, em justificar o próprio pensamento. Frequentemente, e como se pode ver na estrutura de diversas conferências de Vitoria ${ }^{18}$, tal acúmulo de razões a favor tornava-se exagerado, pesado e repetitivo. In casu, parece ser isso mesmo que o teólogo fez. O exemplo da morte do embaixador francês não foi proposto como um caso hipotético a ser ordenado em uma das duas espécies de direito das gentes. Ao contrário, foi mencionado para resolver uma questão mais ampla, já enunciada acima: se o direito das gentes (enquanto gênero) é positivo, e se não está vinculado a nenhuma comunidade em particular, de onde vem sua obrigatoriedade? Para responder a esta pergunta, Vitoria selecionou um exemplo de atualidade em sua época e procurou mostrar que o ius gentium fornecia uma resposta clara ao problema, bem como razões suficientes para que esta fosse seguida pelos países interessados. Passou então, "escolasticamente", a buscar argumentos de todo tipo no sentido da cogência do ius gentium. A primeira destas razões foi, como visto, o consentimen-

17 VITORIA, Francisco de. La justicia. Tradução e introdução de Luis Frayle Delgado. Madri: Tecnos, 2003, pag. 27.

$18 \mathrm{Na}$ Relectio de Indis, por exemplo, o primeiro título legítimo pelo qual os espanhóis poderiam ocupar a América é justificado por nada menos que catorze razões sequencialmente ordenadas. Ver VITORIA, Francisco de. Relectio de Indis. Carta Magna de los Indios. Trad. C. Baciero, org. Luciano Pereña. Col. "Corpus Hispanorum de Pace". Madri: CSIC, 1989. 
to universal. Em paralelo a tal argumento, menciona também o ius gentium particular: caso se prefira acreditar que a inviolabilidade dos legados não valha perante o mundo inteiro, ainda assim ela produziria efeitos perante Espanha e França, pois ambas concluíram acordos particulares a respeito:

\begin{abstract}
En segundo lugar digo que obrar contra el derecho de gentesy violarlo es ilícito, porque de suyo lleva consigo una injusticia que se infiere, y cierta desigualdad. Porque si los franceses consideran inmunes a nuestros embajadores, es necesario que lo mismo consideremos nosotros a los suyos. ${ }^{19}$
\end{abstract}

Além de violar o consenso universal, a eventual morte do embaixador geraria também uma desigualdade concreta na relação bilateral entre Espanha e França. Uma das partes teria se esforçado para garantir a imunidade do diplomata, enquanto que o outro lado abusou da boa-fé de seu vizinho e do próprio enviado para executá-lo, colocando-se em posição mais vantajosa (sujeita a menos restrições) que a primeira.

Existe, portanto, um segundo direito das gentes, referente a pactos entre nações particulares. Tais pactos não necessitam ser escritos: o costume também cria vínculos jurídicos ${ }^{20}$. Da mesma forma que ocorre entre os indivíduos, a relação entre as repúblicas deve pautar-se na igualdade para ser justa. A quebra de um pacto acordado, ainda que somente entre dois soberanos, destrói tal igualdade e é, desta forma, injusta, violando o direito das gentes entre estas nações.

Esta divisão do fundamento do direito das gentes

19 VITORIA, Francisco de. La justicia. Tradução e introdução de Luis Frayle Delgado. Madri: Tecnos, 2003, pag. 28.

20 Em sentido contrário, Haggenmacher defende que o direito das gentes escrito corresponde às regras que foram consagradas pela legislação estatal, enquanto que o não escrito se referiria às outras normas do ius gentium, que não teriam recebido (ainda) guarida do ordenamento jurídico nacional: HAGGENMACHER, Peter. La place de Francisco de Vitoria parmi les fondateurs du droit international. In: TRUYOL SERRA, Antonio et al. Actualité de la pensée juridique de Francisco de Vitoria. Bruxelas: Bruylant, 1988, pag. 64. Acredita-se que este dualismo (como o chama Haggenmacher) não se coaduna com o pensamento vitoriano, pois este não faz referência em nenhum momento a leis internas e menciona, na segunda parte da solução ao exemplo do assassinato do embaixador francês, uma desigualdade entre duas nações, Espanha e França. Parece claro que tal desigualdade não se baseia em legislações nacionais diferentes, e sim em que ambas haviam consentido em manter certo comportamento recíproco, que teria sido alterado bruscamente em seguida. Na De Iure Belli, Vitoria menciona que o direito das gentes sobre proibição de matar prisioneiros cristãos, ainda que culpados pela agressão injusta, foi estabelecido pelo costume e deve ser mantido. (VITORIA, Francisco de. Relectio de Iure Belli o Paz Dinámica. Org. Luciano Pereña. Col. "Corpus Hispanorum de Pacis", vol. 6. Madri: CSIC, 1981, pag. 185) encaixa-se na natureza do mesmo ius gentium, como definida por Vitoria. O primeiro tipo, oriundo de um grande consenso geral, aproxima-se bastante do direito natural, ainda que não se identifique com este. Recorde-se sempre que o direito natural independe do consenso humano, enquanto que o direito das gentes, mesmo nesta primeira acepção, é um fruto do acordo entre as vontades das pessoas ou nações. Porém, no caso do pacto internacional público, Vitoria supõe razoavelmente que um tal acerto só seria alcançado pelos diferentes povos nos casos em que realmente se faça necessário. Isto é, o direito das gentes geral abrange aquelas coisas que são praticamente indispensáveis à convivência humana:

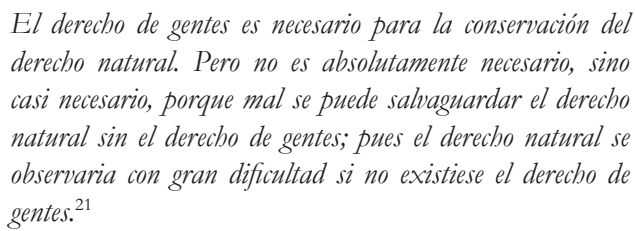

$\mathrm{Na}$ perspectiva tomista que também é a de Vitoria, o direito natural corresponde ao justo por natureza. Isto é, àquilo que, por uma exigência direta da igualdade entre os seres humanos, será devido ao outro em cada relação entre duas ou mais pessoas envolvendo coisas. Por definição, o direito natural não é suscetível de codificação, uma vez que o "justo" mudará de acordo com as circunstâncias concretas de cada relacionamento humano. Santo Tomás evocava um exemplo expressivo quanto a isto, na figura do proprietário de uma arma que, após emprestá-la, se tornasse louco ou inimigo da cidade. Neste caso, é evidente que o direito natural, que antes mandava devolver o objeto, agora impedirá fazê-lo. Aristóteles expressa a mesma ideia ao diferenciar "retaliação" de "retribuição" na Ética a Nicômaco: a retaliação consiste na simples repetição de um ato injusto pela vítima contra o ofensor. Já a retribuição corrige a injustiça através de uma proporção ${ }^{22}$.

Ou seja, pode ser bastante difícil dizer com precisão o que é o justo natural perante algum caso concreto conflituoso. É por isso que se faz necessário o direito positivo: trata-se de uma concretização do direito natural adequada a certas condições mutáveis de tempo e espaço, onde intervém a vontade humana. Segundo Francisco de Vitoria, "se llama positivo porque procede de al-

21 VITORIA, Francisco de. La justicia. Tradução e introdução de Luis Frayle Delgado. Madri: Tecnos, 2003, pag. 29.

22 ARISTÓTELES, Ética a Nicômaco. Tradução de António de Castro Caeiro. São Paulo: Atlas, 2009, pags. 112-115. Livro V, 1132b$1133 b$. 
gún consenso [...] el [derecho] que depende de la voluntad o el beneplácito de los hombres se denomina positivo"23. Porém, como já visto, há uma etapa intermediária entre o direito natural e o positivo: o ius gentium no sentido primário descrito acima por Vitoria é a primeira e mais ampla concretização do direito natural. Será composto pelas exigências mais gerais que correspondem ao modo de vida das comunidades humanas.

Vale destacar que, na tradição jusnaturalista clássica integrada por este dominicano, direito natural e direito positivo não formam dois sistemas jurídicos prontos e acabados, como se se tratasse dos ordenamentos legais de dois países ou de duas "províncias" da ciência jurídica contemporânea, tais como direito contratual, consumeirista, da responsabilidade civil etc. $\mathrm{Na}$ verdade, são duas fontes de um único ordenamento ou sistema jurídico, que é em parte natural e em parte positivo ${ }^{24}$. Esta concepção dos dois direitos permite compreender como o teólogo burgalês pôde manter seu ius gentium em posição intermediária: se ius naturale e ius civile são fontes, e não agrupamentos de preceitos, não haverá contradição em que ambos irriguem o direito das gentes.

Não se olvide que, para Vitoria, como para todo o pensamento escolástico e aristotélico clássico, o homem possui uma natureza comum, compartilhada por todos os integrantes da espécie. Dentre os traços característicos do ser humano, encontra-se a sociabilidade, que o impele a buscar a companhia dos outros e, em última análise, a viver em sociedade e formar esferas particulares de convivência - no tempo de Vitoria, as "repúblicas". Admitindo estes postulados, compreende-se que as várias comunidades humanas espalhadas pelo mundo serão destinatárias de algumas poucas exigências básicas de justiça que serão comuns, por mais que o contexto histórico, geográfico etc. possa variar. Estas exigências básicas compõem o ius gentium vitoriano em seu primeiro sentido.

A lição sobre o artigo $3^{\circ}$ da quaestio 57 fornece alguns exemplos deste direito das nações: a propriedade

23 VITORIA, Francisco de. La justicia. Tradução e introdução de Luis Frayle Delgado. Madri: Tecnos, 2003, pags. 14-15.

24 HERRERA, Daniel A. Op. cit., pag. 56. Também Michel Villey considera direito natural e lei positiva como fontes do direito, sendo que ambos deverão ser aplicados de modo harmônico, orientado pela experiência e pela realidade na busca do que é justo em cada caso concreto. VILLEY, Michel. Filosofia do Direito. São Paulo: Martins Fontes, 2003. Ver especialmente Tomo II, Título Terceiro, Capítulo 3, art. I: pags. 431-440. privada, as regras básicas sobre início e fim das guerras, a inviolabilidade dos embaixadores, a redução dos prisioneiros de guerra à escravidão. São todos padrões de conduta que ele observa tanto na sociedade em que vive (Espanha), quanto na comunidade onde esta se inseria (que pode ter o nome de Cristandade, Sacro Império Romano-Germânico, Europa etc.), quanto entre os povos vizinhos com os quais se mantinham relações (muçulmanos $^{25}$ ). Nenhuma destas exigências é de direito natural, isto é, uma necessidade imediata decorrente da natureza do homem. Mas sem elas, argumenta o regente de Prima, seria quase impossível manter a igualdade entre as pessoas $^{26}$. São, portanto, normas jurídicas que devem ser respeitadas. Decorrem da vontade humana de um modo sutil e indireto: é verdade que os povos do mundo não escolheram explicitamente tais regras. $\mathrm{O}$ "consenso do orbe" se deu através da consagração destas normas essenciais pelo uso, sendo certo que se trata de preceitos quase necessários à vida em sociedade. $\mathrm{O}$ ius gentium vitoriano no sentido primário possui, então, uma dupla raiz: nasce do consentimento geral - isto é, do que é observado entre todas as nações - sempre que tal costume esteja concretizando alguma norma de direito natural. Ao contrário deste último, o direito dos povos não é necessário. Mas representa um modo de aplicar o direito natural à realidade das sociedades humanas. Caso não houvesse o direito das gentes, ainda assim o direito natural poderia teoricamente continuar vigente. $\mathrm{Na}$ prática, contudo, a falta da orientação específica do ius gentium faria com que os homens encontrassem numerosas dificuldades à hora de descobrir e aplicar o ius naturale aos casos litigiosos.

Neste sentido, Juan Cruz Cruz define o direito das gentes de Francisco de Vitoria como um direito complementar, exigível em função de sua conveniência, para que o direito natural seja preservado. O direito das gentes é necessário, embora não absolutamente, devido à realidade antropológica pós-pecado original, o qual fragilizou o interior humano, transtornando suas paixões e tornando mais difícil, quase impossível, encontrar o jus-

25 Aqui ele ainda não menciona os índios americanos, embora a Relectio de Indis, proferida alguns anos depois, venha a ser uma aplicação prática desta doutrina do ius gentium aos nativos do Novo Mundo.

26 O caso específico da escravização dos prisioneiros de guerra, hoje claramente expulso do ius gentium, será discutido mais adiante. Por ora, basta ressaltar que tal direito pode sofrer alterações decorrentes de mudanças decisivas na relação dos indivíduos e das repúblicas. 
to natural em um caso concreto, no qual vontade e razão estarão muito influenciadas pelos afetos sensíveis ${ }^{27}$. Desta maneira, o direito das gentes, como um direito "normal", consagrado pelo uso generalizado, auxilia as pessoas a obedecerem às exigências básicas do direito natural.

É um direito no qual a vontade humana intervém, não através do livre-arbítrio individual (direito civil ou positivo), mas por duas grandes escolhas históricas, feitas por milhares de indivíduos ao longo dos séculos: a determinação do modo de vida que as diferentes sociedades terão em comum e o padrão de condutas básicas adequadas a este modo de vida.

Como se vê, este ius gentium lembra um pouco a proporcionalidade aristotélica: seu conteúdo variará de acordo com as condições gerais da convivência humana. Assim sendo, dentro do próprio conteúdo do ius gentium não se exige uma uniformidade estrita. Modos de vida muito diferentes entre si podem levar a alterações no ius gentium. Vitoria repara nisso, ao mencionar o ius gentium que ainda não foi sancionado para todos os povos. No exemplo do embaixador francês, a pergunta "¿Por qué y cómo sabéis vosotros que nosotros hayamos admitido aquel derecho de gentes y que hayamos pecado matando al enemigo?"28 refere-se a esta mutabilidade interna no direito dos povos: os conterrâneos de Vitoria só poderiam ser responsabilizados juridicamente pela morte do embaixador francês caso estivessem obrigados pela correspondente norma de direito das gentes. Dado que "no todos están obligados a observar el derecho de gentes", é preciso provar que os ibéricos estão entre os povos vinculados por esta regra específica. Para isso, será necessário de início examinar se o preceito em questão compõe o ius gentium primário ou secundário. No primeiro caso, o problema estará resolvido: todos estão vinculados por estas normas de direito das gentes. Já na segunda hipótese, seria preciso outra análise para identificar se o povo em questão concordou - por palavras ou por atos - com aquela norma de ius gentium, que estará baseada no consentimento. Como visto, Vitoria considera que a inviolabilidade dos legados faz parte do primeiro ius gentium. Porém, para fins acadêmicos e ad argumentandum, indica como a questão se resolveria se tal regra estivesse

27 CRUZ CRUZ, Juan: La soportable fragilidad de la ley natural: consignación transitiva del ius gentium en Vitoria. In: CRUZ CRUZ, Juan: Ley y dominio en Francisco de Vitoria. Pamplona: EUNSA, 2008, pags. 24 e seguintes.

28 VITORIA, op.cit., pag. 27. no ius gentium secundário ou particular. Daí a menção à desigualdade que surgiria entre espanhóis e franceses caso o embaixador fosse desrespeitado.

Note-se que o ius gentium particular difere do direito civil na medida em que aquele se refere aos indivíduos enquanto reunidos em comunidades e na medida em que mantêm relações com outros agrupamentos semelhantes. Neste sentido, é um direito distinto do ius civile por ter âmbito de aplicação diverso. Como Vitoria é fiel à tradição organicista do pensamento aristotélico-tomista, ele tende a valorizar mais a comunidade que o indivíduo ${ }^{29}$, refletindo em uma primazia do direito das gentes - obrigação que incumbe aos cidadãos devido a sua organização em república - sobre o direito civil - obrigação decorrente da simples relação entre cidadãos ${ }^{30}$.

Alguns anos mais tarde, ao proferir a célebre conferência "De Indis", Vitoria afirmará que o direito das gentes leva em conta o consentimento da maior parte do orbe, ainda que a menor parte se oponha ${ }^{31}$. Parece

29 Por exemplo: "Todo lo que el hombre es, no sólo en cuanto a sus bienes de fortuna, sino también a los de su naturaleza, constituye un bien de la república. [...] a todo hombre le incumbe la obligación de sacrificarse por la república, y la república puede exponerle para la conservación de si misma, incluso si constase que va a morir; con ello no comete ninguna injusticia, de igual modo que un miembro del cuerpo puede sacrificarse por la salud del todo. [...] La república podrá sacrificar a un hombre, como se hace con un miembro, en favor de la salvación de toda la república. Ésta puede exponer la vida de un inocente por su salvación, si ello es necesario." VITORIA, Francisco de. Comentários à Secunda Secundae da Suma Teológica de Santo Tomás de Aquino, q. 125, a.4. Apud VITORIA, Francisco de. Relectio de Potestate Civili. Estudios sobre su filosofia política. Edição crítica de Jesús Cordero Pando. Madri: CSIC, 2008, pag. 97. Embora "aunque el cuerpo natural y el mistico tengan mucho en común, no lo tienen todo, sino que difieren en algunas cosas. Una parte natural existe precisamente en razón del todo en el cuerpo; pero en la Iglesia cada hombre existe para Dios y para si mismo, y su bien privado no se ordena al bien del todo". VITORIA, Francisco de. Relectio Secunda de Potestate Ecclesiae. Apud VITORIA, Francisco de. Relectio de Potestate Civili. Estudios sobre su filosofia política. Edição crítica de Jesús Cordero Pando. Madri: CSIC, 2008, pag. 97.

30 "Toda la república puede ser licitamente castigada a causa del pecado del rey. Así, si el rey emprendiese una guerra injusta contra cualquier principe, aquél que sufrió la agresión puede alzarse con el botin y ejercer los demás derechos de guerra sobre los súbditos del rey, incluso aunque todos sean inocentes. Este corolario se prueba porque, dado que el rey es instituido por la república, si éste llevase a cabo con insolencia algo indigno, eso se imputa a la república." VITORIA, Francisco de. Relectio de Potestate Civili. Estudios sobre su filosofia política. Edição crítica de Jesús Cordero Pando. Madri: CSIC, 2008, pag. 43.

31 "Obsérvese que si el derecho de gentes tiene en buena parte su origen en el derecho natural, claramente tiene fuerza para conceder derechos y crear obligaciones. Y en el supuesto de que no siempre tenga su origen en el derecho natural, si parece que se tienen en cuenta el consentimiento de la mayor parte del orbe, sobre todo cuando se trata del bien común de todos. Porque si desde los primeros tiem- 
residir aqui uma contradição no pensamento do mestre salmantino: afinal, o direito das gentes obriga ou não os recalcitrantes? A resposta dependerá de qual ius gentium estiver em questão. Tratando-se do ius gentium oriundo de um pacto público, isto é, do consentimento de todas as nações, um país que se opusesse ao direito das gentes estaria operando contra o bem comum, tanto de sua república quanto dos vizinhos. Quando se tratar, por outro lado, de um ius gentium "ainda não sancionado" para um dos lados, isto significa que a norma não corresponde ao modo de vida daquele povo, tampouco ao contexto no qual este se insere. Em outras palavras, aquela república não consentiu com tal preceito. Neste caso, abre-se uma possibilidade de derrogação da norma, pois tratar-se-á do ius gentium particular.

Concluindo esta seção, pode-se sintetizar a divisão vitoriana nos seguintes termos: o direito das gentes não se insere definitivamente no direito natural ou no positivo. Contudo, sua dependência da vontade humana (embora não do livre-arbítrio individual) e sua historicidade (embora só dependa das características mais comuns das sociedades e idiossincrasias culturais específicas não o derroguem) o situam mais próximo ao direito positivo que ao natural.

No interior do ius gentium, encontra-se nova divisão, referente ao modo de produção de normas e aos sujeitos aos quais estas se dirigem. Em um primeiro sentido, o direito das gentes é produto de um virtual pacto público que abrange todas as nações "do orbe". Neste sentido, obrigará todos os povos independentemente de suas características culturais ou do conhecimento que possuam do ius gentium, eis que existem traços da natureza do ser humano que se repetem universalmente, como a tendência constante à sociabilidade e à vida em sociedade. No segundo sentido, o direito das gentes é produto de um pacto particular entre nações específicas. Tal pacto pode dar-se de modo expresso ou pela via consuetudinária. Caso não se esteja diante de um tratado, este segundo tipo de ius gentium será proporcional às características essenciais da coletividade na qual os povos específicos se inserem.

pos de la creación del mundo y de su reconstrucción después del diluvio la mayoría de los hombres estableció que los embajadores en todas partes fueran inviolables, que los mares fueran comunes, que los prisioneros de guerra fueran esclavos, y que asimismo convenía que los extranjeros no fueran expulsados, ciertamente esto tendría fuerza de ley, aun con la oposición de los demás." VITORIA, Francisco de. Relectio de Indis. Carta Magna de los Indios. Trad. C. Baciero, org. Luciano Pereña. Col. "Corpus Hispanorum de Pace". Madri: CSIC, 1989, pag. 102 (Grifo em sublinhado acrescentado.)
É possível, por fim, que o segundo tipo de ius gentium altere o primeiro, desde que isto não cause uma violação ao direito natural. Em outras palavras, que o direito natural seja concretizado de forma mais específica por um grupo restrito de nações do que pelos postulados gerais do primeiro direito das gentes.

Francisco de Vitoria talvez mereça alguma crítica por não ter sido mais sistemático no tratamento desta questão. Afinal, esperar-se-ia do "pai do direito internacional" um estudo mais percuciente acerca da passagem onde Santo Tomás define o direito das gentes. Além disto, é um fato que a divisão do ius gentium aqui descrita só aparece de modo razoavelmente explícito na resolução do caso do embaixador francês. O restante da obra internacionalista de Vitoria não menciona tal distinção.

O que se pode dizer a respeito é que, como já percebido por Peter Haggenmacher ${ }^{32}$, Francisco de Vitoria não imaginava estar criando algo novo quando lecionava sobre o ius gentium, embora acabasse por conferir-lhe importantes nuances de própria lavra. Ele se percebia como seguindo na mesma linha de pensamento que, dos juristas romanos e passando por Santo Isidoro de Sevilha, inspirara as precisas (no direito, nem sempre) definições de Santo Tomás de Aquino. Ao explicar o direito das gentes, o teólogo burgalês tinha por missão tomar elementos da rica tradição sobre o tema e aplicá-los a um problema novo e concreto. Neste sentido, ainda que a bipartição no ius gentium não fosse explicitamente enunciada pelas fontes de Vitoria, este possivelmente teria encontrado alguma correspondência nas páginas da Suma Teológica a respeito. Quando trata por sua vez do tema, não é tão explícito sobre esta divisão do ius gentium, quiçá para manter-se fiel à letra de Santo Tomás. Mas, confrontado pelas questões que ele mesmo se propõe na discussão do texto, acaba por admitir a existência das duas subespécies - postulado coerente com sua concepção de direito e de direito das gentes, como visto ${ }^{33}$.

32 HAGGENMACHER, op. cit., pags. 58-63.

33 Em interessante estudo sobre os sentidos real e atribuído aos Tratados de Paz de Westfália (1648), Luiz Magno Pinto Bastos Junior afirma que a relevância destes instrumentos para a história política está em seu caráter dúplice: eram tanto acordos entre potências equiparadas entre si quanto leis internas do Sacro Império Romano-Germânico. Pensa-se que esta dualidade, que configurou um "sistema multinivelado" no interior do Império, reflete tacitamente a bipartição vitoriana, sendo que as garantias religiosas e institucionais para os súditos do Imperador alemão se enquadram no sentido primário do ius gentium identificado por Vitoria, eis que seriam uma exigência geral dos povos (aqui, da Cristandade). BASTOS JUN- 


\section{OUtRAS INTERPRETAÇÕES DO IUS GENTIUM VITORIANO}

A tese aqui defendida, da existência de duas espécies de ius gentium em Francisco de Vitoria, está longe, ao que parece, de ser majoritária entre os estudiosos do teólogo dominicano. Nesta seção serão mostradas algumas interpretações diferentes do direito das gentes proposto pelo salmantino, com especial atenção a eventuais menções sobre os dois tipos de ius gentium mencionados por Vitoria no comentário à II-II q. 57 a.3.

Em artigo publicado neste periódico ${ }^{34}$, Paulo Emílio de Macedo narra a evolução na recepção e valoração do labor vitoriano ao longo dos séculos, esmerando-se em evidenciar os anacronismos que foram ajuntados, pelos intérpretes, à obra original do mestre salmantino. Acerca da natureza do ius gentium, Macedo entende que esta não era, para Vitoria, questão premente. A ambivalência no trânsito entre direito das gentes público e privado dever-se-ia, para ele, às características do pensamento vitoriano, que estaria apenas derivando o velho conceito romano, de um ius gentium cuja validade e aplicação se cingiam ao interior do Império Romano e ao poder do pretor, para a realidade pós-Descobrimento, de um mundo multirreligioso, porém submetido à jurisdição cristã. Segundo Macedo, quando Vitoria fala em "todo o orbe", está pensando na Respublica Christiana. A proximidade com o direito natural também seria um paralelismo com o típico raciocínio romano, porém sem grande aplicabilidade prática. $\mathrm{O}$ direito das gentes de Francisco de Vitoria seria um direito supranacional, porém intra-Cristandade ${ }^{35}$.

A contribuição deste internacionalista é relevante por buscar situar Vitoria em seu tempo. É imprescindível ter em mente, como ele insiste, que o mundo visto pelo dominicano diferia substancialmente daquele contemplado por seus intérpretes hodiernos. Conceitos

IOR, Luiz Magno Pinto. Rever ou romper com Vestfália? Por uma releitura da efetiva contribuição dos acordos de paz de 1648 à construção do modelo vestfaliano de Estados. Revista de Direito Internacional, Brasília, v. 14, n. 1, 2017, pags. 357-376, esp. pag. 363. Disponível em: < https://www.publicacoesacademicas.uniceub.br/ rdi/article/view/4397 > . Acesso em: 10.07.2017.

34 MACEDO, Paulo Emílio Borges de. O mito de Francisco de Vitoria: defensor dos direitos dos índios ou patriota espanhol? Revista de Direito Internacional, Brasília, v. 9, n. 1, jan./jun. 2012. Disponível em: < https://www.publicacoesacademicas.uniceub.br/ $\mathrm{rdi} /$ article/view/1602/1591 >. Acesso em: 10.07.2017.

35 Idem, pag. 9. como "humanidade" e "orbe" terrestre muito provavelmente evocariam, na mente do palestrante e de seus ouvintes, imagens familiares, relativas ao convívio dos vários príncipes cristãos, mediado por valores religiosos fundamentais e comuns.

Muito embora se conceda que tal era, ao que parece, a perspectiva de Vitoria, mantém-se que o fundamento de seu ius gentium encontra-se detalhado em seu Comentário ao Tratado da Justiça, e que independe da jurisdição cristã. O esquema acima descrito não necessita da chancela religiosa para ser aplicado. E, com efeito, como se verá nos exemplos colacionados mais abaixo, o regente de Prima emprega seu ius gentium, tanto o primário quanto o secundário, a realidades totalmente alheias à Cristandade, como os costumes dos índios e dos nativos africanos.

Discorda-se de Paulo Emílio de Macedo, então, quando indica que o dominicano espanhol não teria ultrapassado, em sua concepção do direito das gentes, a perspectiva romana ${ }^{36}$. Parece, antes, que o segundo aspecto do direito dos povos, aquele dependente do consentimento de nações que estivessem em contato, revela uma ideia incipiente de igualdade entre os diversos povos do mundo, que seria insuportável a um jurista da antiga Roma caput mundi.

Juan Cruz $\mathrm{Cruz}^{37}$ entende o direito das gentes em perspectiva muito próxima da que foi abordada aqui, como a conclusão de um raciocínio em que o direito natural figura como a premissa maior e as fragilidades humanas causadas pelo pecado original formam a premissa menor. Suas proposições são, pois, condicionais ou hipotéticas, não absolutas, embora sejam universais. Trata-se de uma modulação das normas do direito natural causada pelas diversas circunstâncias que podem incidir na vida humana, acrescidas do latente perigo da discórdia entre os homens causada pela desordem instaurada em seu interior após o pecado.

Acerca da divisão estabelecida por Vitoria entre direito das gentes público e particular, Cruz se reporta à distinção feita pelo salmantino no artigo anterior da mesma quaestio, no qual analisava a relação entre direito natural e positivo. Ali, o teólogo afirmava que en otro sentido justo es lo que es igual por la determinación de
una ley o por un pacto privado, y no por su propia naturaleza;
como, por ejemplo, cuánto hay que pagar por un caballo o una

36 Idem, pag. 11.

37 CRUZ CRUZ, op. cit. 
casa, y por el trabajo de un día, etc., no es algo determinado por su propia naturaleza sino por un pacto. $Y$ en este sentido pongamos la segunda conclusión: lo justo en este sentido se denomina derecho positivo e bumano. Y lo justo así entendido unas veces consta por un pacto bumano privado, otras por un pacto público, y esto se llama ley. ${ }^{38}$

Segundo Cruz, a divisão no seio do direito das gentes ocorreria de forma análoga. Haveria um ius gentium público, oriundo de um pacto comum feito pelos representantes dos diversos povos ou nações, e um ius gentium privado, que provém de um consentimento privado e de pactos feitos por indivíduos particulares ${ }^{39}$. O primeiro é exemplificado por ele com o instituto das embaixadas, aproveitando a lição vitoriana. Em relação ao ius gentium privado, Cruz não o desenvolve, tal como Vitoria deixou de fazer. Contudo, analisa diversos exemplos concretos de direito das gentes, dentre os quais é possível enxergar o ius gentium privatum defendido por ele na instituição da propriedade privada e na solenidade do matrimônio ${ }^{40}$. São figuras cujo uso comum se deu a partir da ação de particulares, ao contrário do envio e recepção dos legados diplomáticos.

Esta concepção da bipartição vitoriana do direito das gentes é compartilhada por Peter Haggenmacher ${ }^{41}$ e Mariano Fazio ${ }^{42}$, que acentuam o caráter contratual do direito que será instituído pelo pacto público e sua positividade. Diferem de Cruz ao considerar que o direito das gentes vitoriano, ao menos nesta parte dos Comentários, é predominantemente positivo ${ }^{43}$.

Trata-se de um entendimento um pouco diferente do que foi exposto até aqui. A principal distinção está em que, para Cruz, Haggenmacher e Fazio, o critério de separação usado por Vitoria seria a identidade do criador do ius gentium, que pode ser a comunidade, agindo por seus representantes (ius gentium público), ou as pessoas individuais, atuando em nome próprio (ius gentium privado). Enquanto que nas páginas precedentes o critério era outro: o grau de abrangência da norma, que podia ser geral (ius gentium primário ou público) ou restrito

38 VITORIA, Francisco de. La justicia. Tradução e introdução de Luis Frayle Delgado. Madri: Tecnos, 2003, pag. 14.

39 CRUZ CRUZ, op. cit., pag. 18.

40 Idem, pag. 23.

41 HAGGENMACHER, op. cit., pags. 40-41.

42 FAZIO FERNANDEZ, Mariano. Francisco de Vitoria: cristianismo y modernidad. Buenos Aires: Ciudad Argentina, 1998, pag. 87.

43 Mariano Fazio acrescenta que Vitoria modificará sua perspectiva posteriormente, nas duas Relectiones de Indis, passando a incluir o direito das gentes no direito natural. (ius gentium secundário ou particular). É por isso que, para estes autores, a distinção entre estes dois tipos de direito das gentes é tida como secundária: a identidade do legislador pouco importa, se o ius gentium produzirá sempre os mesmos efeitos.

O raciocínio de Cruz tem o mérito de deixar claro que o direito das gentes se forma também pela soma de diversas condutas individuais autônomas. É certo que a propriedade privada, o caráter solene do matrimônio e alguns outros institutos decorreram de seu uso constante por parte dos indivíduos de diversas nações por um longo período de tempo. Então, faz certo sentido afirmar que o propósito de Vitoria com a distinção foi o mesmo que no momento em que dividiu o ius civile: falar sobre duas possíveis origens do direito estudado.

Por outro lado, o esquema proposto por Cruz, Haggenmacher e Fazio traz um inconveniente: não dá explicação suficiente para eventuais derrogações do ius gentium, cuja admissibilidade Vitoria reconhece expressamente. Com efeito, o direito das gentes originado em um pacto público e o que deve sua existência a um acordo entre particulares não parecem diferir substancialmente quanto a sua obrigatoriedade: os exemplos da propriedade privada e da celebração do matrimônio são citados por Cruz (seguindo Vitoria) ao lado das figuras do tratado de paz e da inviolabilidade dos embaixadores. O fato de estes últimos ordenarem-se ao ius gentium público e os primeiros, ao privado, não modifica em nada seu caráter vinculante.

Além disso, bem examinado o contexto da afirmação vitoriana sobre a bipartição do ius gentium, não parece que ele tivesse em vista a distinção enxergada pelos três estudiosos mencionados ${ }^{44}$. Tanto é que o dominicano retoma, na sequência, o exemplo do embaixador francês, explicando que a eventual morte deste causaria

44 “... hemos sostenido que es doble el derecho de gentes, lo mismo que es doble el derecho positivo, como hemos dicho antes, en el artículo segundo. Uno es positivo por un pacto privado y un consenso, y otro por un pacto público. Asi decimos del derecho de gentes, que uno ha sido hecho por el consentimiento común de todas las gentes y naciones, $y$ en este sentido, los embajadores son admitidos por derecho de gentes, y son inviolables en todas las naciones; pues asi considerado el derecho de gentes se acerca tanto al derecho natural que el derecho natural no puede observarse sin el derecho de gentes. La paz es de derecho natural; si surgen guerras, es necesaria la misión de los embajadores para conseguir la paz. Dicho de otro modo, si los embajadores no fuesen admitidos por derecho de gentes, no podrían apaciguar las guerras. [...] De donde se deduce que siempre es ilicito violar el derecho de gentes, porque va contra el consenso común. En segundo lugar digo que obrar contra el derecho de gentes y violarlo es ilícito, porque de suyo lleva consigo una injusticia que se infiere, y cierta desigualdad." VITORIA, op. cit., pag. 28. 
um desequilíbrio na justiça da relação entre espanhóis e franceses. Não fala em pactos privados entre indivíduos particulares, mas em um padrão de conduta estabelecido entre duas nações, pelo qual uma destas adquiriu o direito de esperar que a outra vá respeitá-lo ${ }^{45}$. Como, na frase seguinte, Vitoria muda de assunto, a interpretação mais fiel à transcrição de sua aula parece ser que, com direito das gentes particular, ele se referia a acordos (escritos ou não) que envolvessem somente algumas das nações do orbe.

Outra ideia a respeito é a de Luiz Henrique Cascelli de Azevedo, que desenvolveu sua tese de doutorado sobre o autor em epígrafe ${ }^{46}$, onde procura traçar uma evolução do pensamento de Vitoria sobre a natureza do ius gentium. Sua hipótese é que nos Comentários à Suma Teológica, este se encontraria próximo ao direito positivo. Contudo, na Relectio de Potestate Civili, já caminharia para mais perto do direito natural. E, por fim, nas Relectiones sobre os índios, Vitoria teria ${ }^{47}$ identificado o direito das gentes com o direito natural ${ }^{48}$. Em relação à alegada etapa de transição, o trecho da conferência sobre o poder civil em que Azevedo se apoia é bastante conhecido:

De todo lo dicho se desprende el siguiente corolario: el Derecho de Gentes no sólo tiene fuerza por el pacto o acuerdo entre los hombres, sino que tiene fuerza de ley. En efecto, el orbe todo, que en cierto modo constituye una única república, tiene el poder de promulgar leyes justas y convenientes para todos, cuales son las del Derecho de Gentes. De donde se sigue que pecan mortalmente quienes violan el derecho de gentes, ya sea en la paz o en la guerra, en los asuntos más graves, como es el no respetar a los legados. No le es lícito a um reino particular no querer atenerse al Derecho de Gentes, ya que ha sido promulgado por la autoridad del orbe entero. ${ }^{49}$

45 "Porque si los franceses consideran inmunes a nuestros embajadores, es necesario que lo mismo consideremos nosotros a los suyos. De donde si, por ejemplo, los embajadores son enviados por una de las partes para restablecer la pazy no son maltratados, si los envía la otra parte y son maltratados, se sigue que hay una desigualdad y una injusticia." Idem, ibidem.

46 AZEVEDO, Luiz Henrique Cascelli de: Ius Gentium em Francisco de Vitoria: a fundamentação dos Direitos Humanos e do Direito Internacional na tradição tomista. Porto Alegre: Sergio Antonio Fabris, 2008.

47 Idem, pags. 147-150.

48 É a mesma opinião de Paulo Emílio V. B. de Macedo, que deixa em aberto outra possibilidade: a de que o dominicano não se preocupava com o direito das gentes nem com seu fundamento. A diferença entre os dois momentos decorreria, nesta segunda hipótese, de sua relativa indiferença pelo conceito. Ver: MACEDO, op. cit., pag. 9.

49 VITORIA, Francisco de. Relectio de Potestate Civili. Estudios sobre su Filosofía Política. Edição crítica de Jesús Cordero Pando. Col. "Corpus Hispanorum de Pace", segunda série, vol. 15. Madri: CSIC, 2008, pag. 63.
A partir desta passagem, Azevedo enfatiza que as violações ao direito das gentes não seriam permitidas por Vitoria, eis que aquele haveria sido estabelecido pela autoridade de todo o orbe, que agiria quase como uma grande república ${ }^{50}$. O autor também lembra que, para o mestre dominicano, a abolição do direito das gentes pelo consenso de todos os povos seria uma impossibilidade prática. Por fim, afirma que, em Vitoria, o direito das gentes se mistura com o direito natural.

Acerca do exemplo do embaixador francês, o estudioso brasileiro pensa que reforça sua hipótese de uma transição do pensamento vitoriano na consideração do ius gentium sucessivamente como positivo ou natural. Para ele, os dois motivos alegados pelo regente de Prima para respeitar a inviolabilidade do enviado de Paris referem-se ao direito natural. Tanto uma disposição dada por autoridade comum do orbe quanto uma certa desigualdade na relação entre dois povos significariam o mesmo: ius gentium e ius naturale possuem o mesmo fundamento de obrigatoriedade ${ }^{51}$. Apesar de transcrever o trecho do Comentário sobre a Suma Teológica em que Vitoria faz a distinção entre pacto público e privado na raiz do ius gentium, Azevedo não lhe confere maior significado.

O trecho da De Potestate Civili acima citado parece eloquente quanto à ordenação do direito das gentes no direito natural. Com efeito, a possibilidade de qualquer opt-out do ius gentium está explicitamente negada, pois este seria fruto da autoridade legislativa de todo o orbe, no qual toda e qualquer nação recalcitrante estará inserida, e para com quem terá obrigações relativas ao bem comum universal. Logo, se este direito se dirige a todas as nações indistintamente e sem consideração pela autoridade particular de uma ou outra república e da vontade de seus membros, parece que se trata de um direito pré-voluntário. Seria um direito natural, ou ao menos algo que se lhe aproxima essencialmente. Perderia o sentido, então, a divisão exposta neste trabalho entre direito das gentes público ou particular, dado que todo ele seria universal e cogente. $\mathrm{O}$ fato de Vitoria repetir a alusão à inviolabilidade dos embaixadores reforçaria a ideia de que esta se fundamenta unicamente em um ius gentium universal.

Contudo, tal afirmação será matizada caso se tome em conta o desenvolvimento da conferência na qual

50 AZEVEDO, op. cit., pag. 150.
51 Idem, pags. 147-149. 
o parágrafo se insere ${ }^{52}$. É preciso notar que Francisco de Vitoria não estava tratando especificamente do ius gentium nesta ocasião. $\mathrm{Na}$ verdade, ele examinava uma questão clássica na história da filosofia política: se o rei estaria obrigado pela lei instituída por si mesmo. Pronuncia-se pela afirmativa, aduzindo duas razões: seria injusto para com os demais cidadãos se o rei, que também é parte da república, não assumisse sua parte na carga dos deveres públicos. Além disso, por ser parte da república, o soberano estaria subordinado a esta e, portanto, à legislação correspondente, ainda que produzida pelo próprio monarca ${ }^{53}$. Desta subordinação do rei à lei, fundamentada na condição de membro da comunidade nacional, Vitoria extrai, como corolário, o princípio de que o ius gentium possui força de lei. Tal propriedade não lhe advém de um pacto entre os homens, mas da vinculação de todos os reinos e nações às regras expedidas pelo orbe, que é o todo do qual fazem parte. Do mesmo modo que o rei, também a república se subordina à lei.

52 J.C. Pando elaborou um ilustrativo esquema da De Potestate Civili, no qual se pode ver que o parágrafo do ius gentium se situa na terceira grande "conclusão" da palestra: a obrigatoriedade das leis civis. Ver VITORIA, op. cit., pag. 310.

53 Este raciocínio vitoriano aplica a chamada teoria da translação do poder civil, da qual foi um grande exponente. Segundo esta teoria, o poder civil provinha de Deus e era delegado pelo Criador aos homens, que instituíam uma autoridade concreta para poder viver em sociedade de acordo com sua natureza sociável. Para conveniência dos homens e de acordo com a lei natural, cada sociedade instituía alguma forma de governo, que passava a deter a autoridade sobre todos. Mas o poder, isto é, a força ordenadora da sociedade, permanecia com os cidadãos tomados em conjunto, em virtude da necessidade da comunidade. VITORIA, op. cit., pags. 21-37, em especial pags. 26-27: "La causa material, en la que ciertamente por derecho natural y divino reside este poder, es la misma república, a la que compete gobernarse y administrarse a sí misma, y dirigir al bien común todos sus poderes. Se prueba porque, si por derecho divino y natural existe algún poder de governar la república, y al margen del común derecho positivo y el sufragio bumano, no existe mayor razón para que semejante poder se sitúe en uno con preferencia a otro, resulta ineludible que la propia comunidad se baste a si misma y tenga este poder. [...] Además, puesto que el cuerpo usa cada miembro para el provecho y utilidad del todo, de modo tal que, si necesario fuera para la integridad del todo, los miembros privados se expongan al peligro y perezcan, no existe razón alguna por la que la república no goce de similar poder, mediante el cual esté capacitada para regir y obligar a sus ciudadanos - como miembros suyos - en vistas a la utilidad y conveniencia del bien público." (No original, o trecho sublinhado se encontra grifado em itálico). Ver também URDANOZ, Teófilo. Sobre la potestad civil - Introducción. In: VITORIA, Francisco de: Obras de Francisco de Vitoria. Relecciones teológicas. Ed. Teófilo Urdanoz. Madri: Biblioteca de Autores Cristianos, 1960, pags. 115-140; e CORDERO PANDO, Jesús. El poder en la república: sus formas y funciones según Francisco de Vitoria. In: VITORIA, Francisco de. Relectio de Potestate Civili. Estudios sobre su Filosofía Política. Edição crítica de Jesús Cordero Pando. Col. "Corpus Hispanorum de Pace", segunda série, vol. 15. Madri: CSIC, 2008, pags. 397-434.
Mas o mestre salmantino não se aprofunda neste tema, do qual poderia retirar diversas conclusões interessantes acerca dos limites do poder civil e de seu exercício para além das fronteiras da república ${ }^{54}$. Ele se contenta em enunciar o corolário e passa, em seguida, a outro tema. Imediatamente após proferir a lapidar frase acerca da obrigatoriedade do ius gentium para todo e qualquer reino, Vitoria começa a explicar a relação entre a razão que originou a lei e a vigência desta, tema em que não menciona o direito das gentes. Pode-se inferir que o mestre salmantino chegou a esta conclusão de modo incidental, mencionando-a para conferir mais interesse a sua conferência e possivelmente como nota mental para o tratamento do tema no futuro ${ }^{55}$. Deste modo, o raciocínio estabelecido no parágrafo é incompleto e não representa uma posição definitiva de Vitoria a respeito do ius gentium. Quando diz que não é lícito a nenhum reino recusar o direito das gentes, isto pode ser entendido como referindo-se ao estabelecido por um pacto público. $O$ fato de ele não mencionar nenhuma outra maneira de derrogação do ius gentium não significa que não possa haver nenhuma em seu pensamento. Talvez não tenha visto necessidade de adentrar a fundo na matéria, obedecendo também a uma promessa feita no início da conferência, de referir-se somente ao que fosse imprescindível para sua investigação acerca da república, "con las menos palabras posibles"

Considere-se ainda que Vitoria menciona, na aludida passagem, que a força do direito das gentes não é retirada somente do pacto entre os homens - reconhecendo implicitamente que o consentimento também é fonte do ius gentium. O fato de ele referir-se a um pacto entre homens, e não entre nações, deve-se novamente ao contexto: na frase seguinte, conclui que violar o direito das gentes é um pecado grave. Ora, só os homens, mas não

54 Como é sabido, as duas relectiones De Indis aplicarão este sentido do ius gentium à situação concreta do relacionamento entre espanhóis e índios por ocasião da conquista da América.

55 Em sentido contrário, Cordero Pando entende que a menção ao direito das gentes seria um ponto central deste discurso de Vitoria, que teria conduzido sua argumentação sobre a obrigatoriedade das leis civis propositalmente a este campo, demonstrando-o como uma consequência necessária e bem fundamentada. CORDERO PANDO, op. cit., pag. 481. Já Haggenmacher confessa que a conclusão extraída por Vitoria é "un peu inattendue" e acrescenta que o propósito do dominicano aqui seria o de afirmar a qualidade jurídica do direito das gentes. HAGGENMACHER, op. cit., pag. 42.

56 VITORIA, Francisco de. Relectio de Potestate Civili. Estudios sobre su Filosofía Política. Edição crítica de Jesús Cordero Pando. Col. "Corpus Hispanorum de Pace", segunda série, vol. 15. Madri: CSIC, 2008, pag. 9. 
os povos, podem pecar.

Visto desta maneira, o fragmento citado parece não se opor à interpretação defendida nestas páginas, de uma divisão entre um ius gentium de caráter público, mais próximo do direito natural, e um de natureza particular, afeto principalmente ao direito positivo ${ }^{57}$.

Além disto, a interpretação de Azevedo parece chocar-se com o método seguido pelo teólogo burgalês na exposição desta palestra: sempre que aborda um tema que julga importante, Vitoria anuncia qual a questão a ser discutida, aduzindo razões favoráveis e contrárias a seu ponto de vista. Ele também recorre rotineiramente ao expediente de enumerar as conclusões que irão estruturando o raciocínio seguido em toda a Relectio. E, demonstrando haver preparado diligentemente a dissertação, não retorna uma vez sequer ao que já foi exposto: seu pensamento progride linearmente e de forma organizada ao longo dos minutos da conferência. Ora, o corolário acerca da obrigatoriedade do ius gentium é apresentado como "el siguiente corolario" que se desprende do que foi dito antes. O palestrante não lhe dá um número e não o enuncia como ponto de partida para uma série de argumentos a favor e contrários. Logo a seguir, o abandona e não retorna ao mesmo, que também não possui nenhum papel relevante na fundamentação das grandes conclusões da Relectio. Portanto, o ius gentium aqui é somente um convidado de segunda categoria, e a passagem que trata do mesmo não pode ser tomada como representativa do pensamento completo do dominicano sobre o tema na ocasião.

Contra a tese da evolução do pensamento vitoriano sobre a natureza do ius gentium estão também as datas conhecidas de suas aulas e palestras: Francisco de Vitoria explicou a Secunda Secundae da Suma Teológica durante os anos letivos de 1526-1529 e 1534-153758. A De Potestate Civili data de $1528^{59}$, isto é, foi proferida durante o primeiro curso vitoriano, mais precisamente

\footnotetext{
57 "Est-ce à dire que la conception contractuelle développée dans le Commentaire sur la Somme théologique soit abandonée? Il est certain que le méchanisme thomiste des condicta publica, qui y avait justifié la force obligatoire du ius gentium, n'est plus guère apparent. Mais les deux conceptions ne sont pas pour autant incompatibles. Ramener le droit des gens à l'une de ces conventions publiques, on l'a vu, revenait implicitement à lui reconnaître une nature légale. Inversement, son aspect conventionnel n'est pas rejeté dans la Leçon sur le pouvoir civil, pas plus que ne l'est l'universalité requise pour la validité de cette loi." HAGGENMACHER, op. cit., pag. 42. As expressões sublinhadas se encontram grifadas em itálico no original.

58 Idem, pag. 40.

59 URDANOZ, op. cit., pag. 108.
}

no momento em que as aulas versavam sobre a virtude da justiça. Contudo, a maior parte dos manuscritos das lições vitorianas (inclusive os que serviram de base às edições consultadas no presente estudo) datam do segundo ciclo de aulas, sendo certo que a parte relativa à justiça foi ministrada em fins de $1535^{60}$. Portanto, a conferência sobre o poder civil não pode ser considerada uma etapa de transição posterior aos Comentários, pois estes reafirmam a posição original de Vitoria sete anos após a Relectio. Se há discordâncias entre ambos os textos, não podem ser atribuídas a uma mudança de opinião de Vitoria.

Teófilo Urdanoz esposa uma terceira opinião sobre a divisão do ius gentium vitoriano. Segundo ele, o mestre salmantino haveria preconizado um direito de gentes de índole natural e um positivo ${ }^{61}$. O primeiro referir-se-ia às normas de direito natural que incidiriam sobre as relações entre as nações, a partir de seu pertencimento ao totus orbis ou comunidade universal ${ }^{62}$. Ao lado deste, haveria um outro, positivo, complementar às normas de direito das gentes natural e incumbido do governo de todo o orbe. O legislador deste ius gentium positivo seria a própria comunidade mundial ${ }^{63}$. Tais normas poderiam revestir tanto a forma escrita quanto consuetudinária, sendo que na primeira categoria entrariam também pactos ou convênios particulares, que vinculariam apenas as nações que a eles aderissem. Mas este direito positivo das gentes iria muito além: Urdanoz é especialmente enfático acerca da possibilidade de atividade legislativa da "comunidade das nações", citando em seu apoio o já estudado trecho da De Potestate Civili sobre a obrigatoriedade do ius gentium ${ }^{64}$. Tratar-se-ia de um direito próprio

60 FRAYLE DELGADO, Luis. Estudio preliminar. In: VITORIA, Francisco de. La justicia. Tradução e introdução de Luis Frayle Delgado. Madri: Tecnos, 2003, pag. XVI.

61 URDANOZ, Teófilo. Introducción a la primera relección. In: VITORIA, Francisco de. Obras de Francisco de Vitoria. Relecciones teológicas. Org. Teófilo Urdanoz. Madri: Biblioteca de Autores Cristianos, 1960, pag. 586.

62 URDANOZ, Teófilo. Síntesis teológico-jurídica de la doctrina de Vitoria. In: VITORIA, Francisco de. Relectio de Indis o libertad de los indios. Trad. L. Pereña e J.M. Perez Prendes, Org. Luciano Pereña. Col. "Corpus Hispanorum de Pace”, vol. 5. Madri: CSIC, 1967, pags. CXXX-CXXXIII.

63 Idem, pag. CXXXIII.

64 Idem, pag. CXXXIV. O trecho vitoriano em questão é: "El Derecho de Gentes no sólo tiene fuerza por el pacto o acuerdo entre los hombres, sino que tiene fuerza de ley. En efecto, el orbe todo, que en cierto modo constituye una única república, tiene el poder de promulgar leyes justas y convenientes para todos, cuales son las del Derecho de Gentes." VITORIA, Francisco de. Relectio de Potestate Civili. Estudios sobre su Filosofía Política. Edição crítica de Jesús Cordero Pando. Col. "Corpus Hispanorum 
da comunidade universal que, ademais, seria regido pelo princípio da maioria, como preceituado por Vitoria na De Indis. Isto é, a comunidade universal teria a faculdade de ditar normas positivas obrigatórias para os distintos países ${ }^{65}$. Para isso, sempre segundo Urdanoz, deveria contar com instituições próprias representativas, nas quais as decisões fossem tomadas e submetidas ao escrutínio da maioria ${ }^{66}$. Por fim, tratando do conteúdo do direito das gentes, tanto natural quanto positivo, Urdanoz sublinha que, em Vitoria, aparece uma primeira formulação de catálogo de direitos fundamentais ${ }^{67}$ quando o mestre salmantino debate o problema da legitimidade da colonização espanhola das Américas. Este rol de direitos básicos dos indivíduos e dos Estados surgiria como uma concretização do direito natural. Por exemplo, da concepção primordial da sociabilidade humana, o teólogo burgalês haveria extraído seu ius comunicationis, estribo de direitos fundamentais como o direito de ingresso em país estrangeiro e de saída do próprio, as liberdades de navegação e comércio, o direito de residên-

de Pace", segunda série, vol. 15. Madri: CSIC, 2008 (No original, o trecho sublinhado se encontra grifado em itálico.)

65 "En él [Vitoria] se establece una clara contraposición entre un derecho internacional de tipo contractual - el de los tratados o convenciones mutuas - y el verdadero derecho positivo de leyes internacionales, emanadas de esa autoridad supranacional. Este es el que obliga a todos los Estados, pues 'ninguno puede sustraerse a su obligación'." URDANOZ, Teófilo. Introducción a la primera relección. In: VITORIA, Francisco de. Obras de Francisco de Vitoria. Relecciones teológicas. Ed. Teófilo Urdanoz. Madri: Biblioteca de Autores Cristianos, 1960, pag. 591. (No original, os trechos sublinhados se encontram grifados em itálico.)

66 URDANOZ, Teófilo. Síntesis teológico-jurídica de la doctrina de Vitoria. In: VITORIA, Francisco de. Relectio de Indis o libertad de los indios. Trad. L. Pereña e J.M. Perez Prendes, org. Luciano Pereña. Col. "Corpus Hispanorum de Pace", vol. 5. Madri: CSIC, 1967, pag. CXXXIV, onde também se lê: "La puerta queda así abierta para toda futura actividad legisladora de la autoridad mundial ya organizada. Los acuerdos de este Organismo de las Naciones Unidas deberían obligar a todos porque van impuestas por la autoridad superior de la Comunidad universal, representada en la mayoría. Todavía no se ha llegado a dar tal eficacia obligatoria a un cuerpo de leyes del derecho internacional positivo, fuera de parciales convenios legislativos." Na introdução à Relectio de Indis Prior, Urdanoz esclarece que Vitoria havia "preconizado" a sociedade de nações com autoridade supranacional, mas não como uma exigência imediata do direito das gentes de sua época. Contudo, este compilador da obra vitoriana manifesta que na época presente a união das nações seria cada vez mais urgente. URDANOZ, Teófilo. Introducción a la primera relección. In: VITORIA, Francisco de. Obras de Francisco de Vitoria. Relecciones teológicas. Ed. Teófilo Urdanoz. Madri: Biblioteca de Autores Cristianos, 1960, pags. 584-585.

67 URDANOZ, Teófilo. Síntesis teológico-jurídica de la doctrina de Vitoria. In: VITORIA, Francisco de. Relectio de Indis o libertad de los indios. Trad. L. Pereña e J.M. Perez Prendes, org. Luciano Pereña. Col. "Corpus Hispanorum de Pace", vol. 5. Madri: CSIC, 1967, pag. XXXVII. cia e trabalho de estrangeiros etc. ${ }^{68}$ Seriam decorrências da parte natural do direito das gentes, que se imporiam a todas as nações do orbe - tanto que Vitoria justifica o ataque armado aos índios que eventualmente obstruam tais faculdades ${ }^{69}$.

Esta interpretação da doutrina vitoriana do ius gentium por Teófilo Urdanoz possui duas grandes vantagens. Em primeiro lugar, revela a ligação que existe, dentro do direito dos povos, entre direito natural e positivo. $\mathrm{O}$ autor estabeleceu algumas prerrogativas fundamentais que competiriam a nações e indivíduos a partir do método vitoriano de extrair conclusões do direito natural. Mas também reconheceu que "o orbe", através de alguma espécie de consenso ou votação, poderia criar regras próprias, de cunho positivo, isto é, não necessário como reflexo do direito natural, e impô-las a todas as nações. Além disso, alguns Estados específicos poderiam criar normas que só valessem entre si, em espírito contratual. Direito das gentes natural e positivo estariam, assim, umbilicalmente ligados. A interrogação que Vitoria propunha a seus alunos quando estudavam Santo Tomás - o direito das gentes é natural ou positivo? - seria respondida pelo mestre salmantino, de acordo com Urdanoz, nos dois sentidos. O fundamento e as primeiras determinações são naturais, as derivações construídas com base nisso são positivas.

A segunda qualidade da posição de Urdanoz refere-se ao catálogo de direitos fundamentais que este autor encontra em Vitoria. Seriam exigências decorrentes do modo de vida humano. Suficientemente genéricas, para abranger as várias comunidades existentes, e específicas o bastante para conferir direitos e deveres aos

68 O rol completo pode ser visto em: URDANOZ, Teófilo. Introducción a la primera relección. In: VITORIA, Francisco de. Obras de Francisco de Vitoria. Relecciones teológicas. Ed. Teófilo Urdanoz. Madri: Biblioteca de Autores Cristianos, 1960, pags. 594612

69 "Si los indios quisieran negar a los españoles el derecho de gentes en los puntos arriba indicados, por ejemplo, el comercio y demás derechos señalados, los españoles deben primero con razones y por la vía de la persuasión evitar el escândalo y demostrar por todos los medios que no vienen a hacerles daño, sino que quieren residir pacificamente y emigrar allá sin causarles daño alguno [...] Pero si tras estas pruebas los indios no quieren darse por satisfechos, sino que acuden a la violencia, los españoles pueden defenderse y tomar todas las precauciones convenientes a su seguridad, porque licito es repeler la fuerza con la fuerza. Y no sólo esto; si no bubiera otra solución, pueden con autorización del principe perseguirla con la guerra y poner en juego los demás derechos de la guerra." VITORIA, Francisco de. Relectio de Indis. Carta Magna de los Indios. Trad. C. Baciero, org. Luciano Pereña. Col. "Corpus Hispanorum de Pace”. Madri: CSIC, 1989, pag. 103. (O trecho sublinhado encontra-se grifado em itálico no original.) 
participantes das relações internacionais. Neste sentido, é interessante a contribuição de Johannes Thumfart que denomina os dois aspectos do ius gentium vitoriano como ius cogens naturale e ius cogens positivum, identificando o primeiro sobretudo com o direito universal de comunicação, do qual outros direitos fundamentais se derivariam $^{70}$. O restante do direito das gentes seria de natureza positiva, destacando-se, para este autor alemão, seu caráter democrático, eis que poderia ser modificado pela maior parte do orbe e até mesmo, em tese, abolido por um consenso universal ${ }^{71}$. Esta identificação do direito das gentes vitoriano com o ius cogens possui seus méritos, sobretudo em relação aos direitos humanos fundamentais.

É preciso frisar que estes dois estudiosos diferem em relação ao aspecto que predomina em Vitoria: Urdanoz pensa que o ius gentium é fundamentalmente natural, enquanto que Thumfart o enxerga como principalmente positivo. Para as necessidades do presente trabalho, contudo, importa mais a semelhança entre ambos, consistente na relação entre direito natural e positivo no ius gentium vitoriano e no papel decisivo que a maior parte do orbe joga no estabelecimento das normas correspondentes.

Contudo, estes posicionamentos podem ser criticados por, mais uma vez, não explicarem de modo satisfatório a possibilidade de derrogação do ius gentium expressamente reconhecida por Vitoria. Se a vontade da maioria é decisiva para a formação do direito dos povos, como explicar que em alguns casos uma minoria de nações possa colocar-se deliberadamente fora deste, como afirma o dominicano acerca da escravidão ou do próprio envio de diplomatas? A concepção de Urdanoz e Thumfart parece pecar por excesso de institucionalismo, ao enxergar na communitas totius orbis uma verdadeira potência legiferante dotada de autoridade supranacio$\mathrm{nal}^{72}$. Ainda que haja trechos das lições vitorianas que corroborem tal tese, esta se mostra inadequada perante sua clara afirmação de que algumas regras do ius gentium

70 THUMFART, Johannes. Die Begründung der globalpolitischen Philosophie: Francisco de Vitorias Vorlesung über die Entdeckung Amerikas im ideengeschichtlichen Kontext. Berlim: Kulturverlag Kadmos, 2012, pag. 20.

71 Idem, pags. 135-136.

72 Ainda que Thumfart, à diferença de Urdanoz, reconheça expressamente que Vitoria não tinha em mente a configuração estatal atual, ele afirma que o orbe poderia instituir democraticamente normas de direito internacional positivo, dependentes da vontade da maioria (Idem, pags. 134-138). só teriam validade para as nações que o aceitassem, tal como ocorre em um pacto entre pessoas particulares. De todo modo, o tratamento dado por Vitoria ao ius gentium, seja nos Comentários, seja nas Relectiones, não autoriza afirmar que pensava em qualquer tipo de organização internacional ou comunidade universal regida pelo princípio democrático. Quando menciona o poder do totus orbis de conferir leis a si mesmo, não parece ter em mente uma atividade normativa no modelo dos atuais foros internacionais, muito menos inspirada nos poderes legislativos internos. Afinal, o orbe só era equiparado a uma república "de certo modo", em alguns aspectos. $\mathrm{O}$ dominicano certamente não enxergava na comunidade universal as mesmas características - nem em ato, nem em potência - que nas "comunidades perfeitas" por ele denominadas de repúblicas ${ }^{73}$. A gênese consensual do ius gentium consistia, como ele mesmo dizia, em um acordo virtual ${ }^{74}$. Portanto, prescinde-se de instituições supranacionais.

\section{Algumas provas da duplicidade do ius gentium em Francisco de Vitoria}

É possível objetar que o exemplo do homicídio do embaixador francês, que originou a presente discussão, não forneceria base suficiente para as conclusões extraídas neste estudo. Afinal, se Vitoria menciona um ius gentium público e um privado, é verdade que ele não se detém sobre este aspecto nem adere especificamente à interpretação exposta nestas páginas, de acordo com a qual o critério para a distinção mencionada seria a abrangência das normas do direito das gentes.

Porém, pensa-se que a separação entre ius gentium universal e particular está bem mais enraizada no pensamento vitoriano que a confusa passagem sobre a

73 Neste sentido, Mariano Fazio e Pedro Mercado Cepeda destacam que o totus orbis de Vitoria possui mais relação com as dimensões social e política dos indivíduos do que com a vontade associativa dos Estados. A comunidade do orbe em Vitoria se diferenciaria da república porque se orientaria por um bem próprio, diferente do bem comum de cada sociedade. Os autores relacionam tal finalidade à dignidade humana. Seja como for, são enfáticos em afirmar que o orbis de Vitoria não pode ser concebido como um Estado. FAZIO, Mariano e MERCADO CEPEDA, Pedro. Las dimensiones política y jurídica del totus orbis en Francisco de Vitoria. In: CRUZ CRUZ, Juan (org.). Ley y domínio en Francisco de Vitoria. Pamplona: EUNSA, 2008, pags. 205-225.

74 VITORIA, Francisco de. La justicia. Tradução e introdução de Luis Frayle Delgado. Madri: Tecnos, 2003, pag. 29. 
má sorte do enviado francês faz crer. Concede-se que o exemplo de aula não foi dos mais felizes. Contudo, quando trata de casos concretos à luz do direito das gentes, o mestre salmantino retorna ao raciocínio que foi aqui descrito. Esta seção traz algumas soluções vitorianas nas quais a duplicidade do ius gentium fica aparente.

$\mathrm{Na}$ lição sobre a justiça, Vitoria menciona um caso em que o direito das gentes poderia ser derrogado em parte: os povos cristãos haveriam anulado em suas relações mútuas o preceito que permitia a escravização dos que fossem capturados em guerra justa ${ }^{75}$. Tal assertiva já fora estabelecida pelo teólogo burgalês cerca de um ano antes, ao comentar a célebre Quaestio de Bello da Suma Teológica:

Duda catorce: ¿Los prisioneros de guerra son esclavos?

Respuesta: En otro tiempo parecía ser esto de derecho de gentes. En efecto, en tiempo de los romanos se observaba, al parecer, la norma de que los prisioneros de guerra quedaban esclavos.

Segunda afirmación de acuerdo con Pedro Palude: Aun en el caso de que se les haya becho prisioneros justamente, los cristianos abora no pueden ser reducidos a esclavitud, ni siquiera en guerra justa. La prueba está en que pueden hacer testamento asi como poseer bienes propios, cosa que no está permitida a los esclavos.

Tercera afirmación: Si se trata de otras personas - paganos y moros, por ejemplo - los prisioneros de guerra son esclavos, si la guerra con ellos es justa, se entiende; porque si no es justa, nunca se puede hacer esclavos a los prisioneros. Esta es la verdadera doctrina. ${ }^{76}$

Por fim, na Relectio de Iure Belli, Francisco de Vitoria reforça tal proibição, considerando que os soldados cristãos poderiam pedir resgate por prisioneiros da mesma fé, mas nunca vende-los como escravos ${ }^{77}$.

É importante ressaltar que a exceção não se baseia em um preceito de direito natural - caso em que seria obrigatória em todo e qualquer conflito - nem na superioridade moral dos cristãos. Nas três vezes em que menciona tal proibição, Vitoria sequer a valora positivamente, limitando-se a constatar que os cristãos chegaram a um acordo neste sentido, o qual haveria adquirido

75 Idem, pag. 30.

76 VITORIA, Francisco de. Quaestio de Bello. In: VITORIA, Francisco de. Relectio de Iure Belli o Paz Dinámica. Org. Luciano Pereña. Col. "Corpus Hispanorum de Pacis", vol. 6. Madri: CSIC, 1981, pags. 238-239.

77 VITORIA, Francisco de. Relectio de Iure Belli o Paz Dinámica. Org. Luciano Pereña. Col. "Corpus Hispanorum de Pacis”, vol. 6. Madri: CSIC, 1981, pag. 177. força obrigatória. Note-se que esta atitude passivamente descritiva não é sempre adotada pelo teólogo em suas obras, como pode ser visto na própria explicação sobre a guerra em Tomás de Aquino. Ali, imediatamente após enunciar sobriamente o costume cristão de não fazer prisioneiros nas guerras travadas no seio da Cristandade, Vitoria se interroga sobre a licitude de causar prejuízo ao inimigo sem que haja uma necessidade militar por trás. Fazendo referência a incêndios de vilas e queima de colheitas, o espanhol condena tais ações em termos fortes, chamando-as de caprichos diabólicos e fogo infernal ${ }^{78}$. Tal vivacidade contrasta com a aparente tranquilidade na qual Vitoria analisa a redução dos prisioneiros de guerra a escravos. Tudo isso confirma que, para ele, a melhora na situação dos capturados em combate se devia unicamente à mudança no padrão de conduta dos povos cristãos em suas guerras recíprocas. O fato de que o resultado concreto fosse mais humano não intervinha em suas considerações. Não se podiam fazer escravos dos prisioneiros de guerra cristãos por causa de uma alteração no ius gentium. Em contrapartida, no tocante aos não cristãos, o antigo preceito comum não fora alterado, e seguiria valendo a permissão de escravizar os cativos. O único reparo que Vitoria faz neste ponto é que a guerra deve ser justa; do contrário, a injustiça do combate inquinaria seus resultados, e não existiria motivo defensável para tolher a liberdade dos indivíduos que não haviam feito mal algum, nem por atos próprios, nem por ações de sua república ${ }^{79}$.

78 VITORIA, Francisco de. Quaestio de Bello. In: VITORIA, Francisco de. Relectio de Iure Belli o Paz Dinámica. Org. Luciano Pereña. Col. "Corpus Hispanorum de Pacis", vol. 6. Madri: CSIC, 1981, pag. 239.

79 Na De Iure Belli, Francisco de Vitoria chega a uma conclusão semelhante em relação à permissibilidade de matar os culpados (isto é, os inimigos que agiram de modo malicioso e que não foram levados à guerra por ignorância ou por simples obediência de boa fé ao seu rei): em uma guerra contra pagãos, ou dos pagãos contra os cristãos, esta medida extrema poderia ser a única maneira de obter segurança após a vitória. Porém "en la guerra [de cristianos] contra cristianos yo no pienso que sea lícito obrar asî", em vista das calamidades e sofrimentos que decorreriam. A razão aqui parece ser um pouco diversa, pois o conferencista não menciona o direito das gentes ou algum acordo especial, preferindo enfatizar o dever do príncipe para com o bem comum. Contudo, parece claro que a morte de todos os inimigos é proibida nos casos em que a proximidade religiosa, social e cultural possibilitaria que a paz fosse mantida por meios menos violentos (derrogação do ius gentium geral por uma situação específica, que exigiria uma regra de ius gentium particular), ao passo que, nos embates contra povos muito diferentes, para com os quais a desconfiança recíproca seria muito grande, os modos de assegurar a paz fossem mais restritos, justificando por vezes o massacre dos perdedores culpados (regra geral do ius gentium, em aplicação estrita 
Neste sentido deve ser interpretada a carta ao padre Bernardino de Vique sobre o comércio de escravos promovido pelos portugueses, na qual tal instituição é reconhecida sem críticas e seus beneficiários são amplamente defendidos. Na missiva, Vitoria respondia a algumas dúvidas de um seu correligionário acerca do procedimento dos lusos em relação aos africanos que eles tomavam como escravos. Aparentemente, diversos compradores (inclusive espanhóis) se viam às voltas com problemas de consciência, não por duvidar da licitude da escravidão em si, mas devido ao temor de que os portugueses houvessem escravizado aqueles indivíduos injustamente, fora do contexto habitual da guerra justa. Uma das questões propostas a Vitoria era qual a possível culpa de um comprador de escravos obtidos originalmente por um ataque injusto dos europeus ${ }^{80}$. A resposta do autor da De Indis é mais legalista do que se poderia esperar dele:

\begin{abstract}
A la otra duda, de los que en sus tierras fueron hechos esclavos en la guerra, tampoco veo por dónde les facer grand escrúpulo, porque los portugueses no son obligados a averiguar las justicias de las guerras entre los bárbaros. Basta que éste es esclavo, sea de hecho o de derecho, y yo le compro llanamente. ${ }^{81}$ (Grafia original mantida.)
\end{abstract}

A aparente insensibilidade de Vitoria pode chocar o leitor deste trecho. Em outras passagens do mesmo documento, ele retoma seus habituais apelos por um tratamento humano dos escravos ${ }^{82}$. Na passagem acima transcrita, porém, deseja-se chamar a atenção para o respeito tributado pelo salmantino aos costumes africanos, eis que a maioria dos escravos traficados pelos lusitanos naquela época lhes eram fornecidos por ou-

da doutrina da guerra justa).

80 Segundo informa o pe. Miguel de Arcos, também correspondente de Vitoria e que guardou a carta ao pe. Vique fazendo algumas anotações à margem para melhor entendimento. VITORIA, Francisco de. El tráfico de esclavos realizado por los portugueses. Fragmento de una carta al padre Bernardino de Vique. In: VITORIA, Francisco de. Relecciones sobre los indios y el derecho de guerra, $3^{\text {a }}$ ed. Madri: Espasa-Calpe, 1975, pag. 24.

81 Idem, pag. 23.

82 "In particulari de los esclavos que los portugueses traen de su India, sin duda si se tuviese por cierto que los portugueses se alzan con ellos por aquella forma y ruindad, yo no sé por dónde los pueda nadie tener por esclavos. Yo no creo que aquél sea trato, a lo menos común de los portugueses, aunque alguna vez haya acaescido; ni es verisimle que el rey de Portugal permitiese tan gran inbumanidad, ni que faltase alguno que le advirtiese dello." (Grafia original mantida. O trecho grifado encontrava-se em itálico no original.) Idem, pag. 22. Também: "Mayor escrúpulo y más que escrúpulo es que ordinariamente los traen inbumanamente, no se acordando los señores que aquéllos son sus prójimos, y de lo que dice sant Pablo, que el señor y el siervo tienen otro Señor a quien el uno y el otro han de dar cuenta." (Grafia original mantida.) Idem, pag. 23. tras tribos nativas, consistindo em combatentes inimigos capturados. Como já visto, Vitoria postulava que, fora da exceção vigente entre povos cristãos por causa de sua tradição específica, seria lícito escravizar os prisioneiros em uma guerra justa. À dúvida sobre a justiça das guerras que se davam entre os nativos, o regente de Prima responde que esta devia presumir-se, sempre que não houvesse maneira segura de estabelecer os fatos. Admitindo-se que os africanos pudessem guerrear justamente uns com os outros, a licitude da captura e subsequente comercialização de escravos seria a consequência lógica ${ }^{83}$. Este seria a outra face da proibição de fazer servos na guerra entre cristãos: coerentemente, o teólogo dominicano reconhece que os demais povos estão sujeitos ao ius gentium geral, sem as restrições introduzidas consuetudinariamente na Cristandade.

De todo modo, como Jesús Cordero Pando já evidenciou $^{84}$, a aceitação da escravidão por parte de Vitoria acaba sendo uma prova a mais da vitalidade de seu pensamento. Pois sua teoria do ius gentium se mantém íntegra ainda que se rechace o exemplo da escravidão. Com os olhos de hoje, é possível enquadrar a escravidão dos inimigos vencidos como um instituto de ius gentium particular (e não geral, como entendia Vitoria), que foi subsequentemente derrogado pela mudança nas condições de vida das comunidades humanas ${ }^{85}$. A distinção

83 A propósito desta passagem, Johannes Thumfart escreve que as condenações que Francisco de Vitoria expressará contra a conquista espanhola das Américas não se devem a pensamentos humanitários ou pacifistas, mas somente à má utilização da categoria do bellum iustum. É verdade que o estilo de Vitoria é sóbrio quando trata de questões jurídicas. Mas não se concorda com a assertiva de Thumfart de que o ius gentium vitoriano seria "positivista" por causa desta grande atenção à forma dos institutos jurídicos e à falta de uma condenação explícita da escravidão. Imagina-se, ao contrário, que o próprio Vitoria responderia que a correta compreensão do conteúdo do ius gentium seria essencial para alcançar a paz entre os povos, incluindo aí o respeito a costumes diferentes ou até mesmo (em certa medida) repugnantes. THUMFART, op. cit., pags. 142-145. 84 CORDERO PANDO, op. cit., pags. 479-480.

85 Também é possível interpretá-la como resultado de um grande erro de apreciação das sociedades humanas, que resultou em uma massiva violação ao direito natual, como prefere Cordero Pando. "Así considerado, como explicitación racional, a lo largo de la historia, del derecho natural, va adquiriendo contenidos que, en algún caso, como en el aludido de la esclavitud, pueden deberse a la insuficiencia de racionalidad o al error bumano, que tendrán que ir superándose con el tiempo." Idem, pag. 480. Embora se concorde com as razões desta argumentação, surge a dúvida sobre o grau de sua dependência das categorias de pensamento e condições sociais típicas dos últimos séculos - e a consequente invalidade de sua aplicação a contextos distintos, como o mundo atlântico do século XVI. Este debate, contudo, não possui importância para o presente estudo. 
entre os dois tipos de direito das gentes parece útil neste aspecto.

Retornando à De Iure Belli, é interessante continuar a estudar a lição de Francisco de Vitoria sobre o tratamento a ser dado aos prisioneiros de guerra. Já que não podem ser escravizados (na guerra entre cristãos), seria lícito matá-los? O conferencista pensa que nada se opõe em princípio a executar os "culpados" após uma guerra justa, "guardando, sin embargo, la equidad". Mas logo abranda esta sentença, consignando que

\begin{abstract}
Como en la guerra bay muchas cosas establecidas por derecho de gentes, parece admitido por la costumbre que, obtenida la victoria y pasado el peligro, no se dé muerte a los prisioneros a no ser que sean prófugos. Y se ha de observar este derecho de gentes en la forma en que acostumbran a guardarlo los hombres rectos. Respecto de los que se han entregado, no be leido ni oído que exista semejante costumbre. ${ }^{86}$
\end{abstract}

Como se vê, a solução mais humana que Vitoria alcança é fruto do costume bélico. A conclusão poderia facilmente correr no sentido inverso, caso os povos então conhecidos pelo teólogo cultivassem o hábito de passar os vencidos à espada. Embora certamente se preferisse uma exortação ao tratamento benévolo dos vencidos em razão de sua comum humanidade, não se deve perder de vista que o direito das gentes aqui adquire coloração nitidamente positiva e variável. Também é possível entrever o outro ius gentium, universal e permanente, na segunda frase do trecho copiado: ainda que certo conteúdo do direito das gentes possa alterar-se, o dever formal de respeitá-lo vale para todos.

Vitoria reconhece que o costume neste caso não é tão sólido quanto desejável, e acrescenta que, por isso,

\footnotetext{
en la rendición de fortalezas de ciudades los que se han entregado suelen tener cuidado de poner condiciones con las que puedan salvar la vida y ponerse a salvo, quiero decir, temerosos de que se les dé muerte si se entregan sin más y sin condición alguna. Y esto leemos que ya se ba hecho algunas veces. Por lo cual no parece inicuo que si una ciudad se entrega sin condiciones, algunos de los más culpables sean ejecutados por mandato del príncipe o del jue $z^{87}$
}

Novamente pode-se apreciar o confronto entre o ius gentium público e o privado. No caso, o dominicano admite que pode haver dúvidas sobre o teor exato do direito das gentes no tocante à sorte dos derrotados. Recomenda, assim, que as cidades sitiadas que desejem

86 VITORIA, Francisco de. Relectio de Iure Belli o Paz Dinámica. Org. Luciano Pereña. Col. "Corpus Hispanorum de Pacis”, vol. 6. Madri: CSIC, 1981, pags. 185-187.

87 Idem, pag. 187. entregar-se pactuem com os atacantes, de modo que estes se vejam obrigados a respeitar a vida dos combatentes. Tratar-se-ia de um ius gentium privado, isto é, oriundo de um acordo específico entre as partes, que derrogaria o direito das gentes geral. Recorde-se que isto é permitido sempre que a derrogação não fira o direito natural. $\mathrm{Na}$ hipótese presente, o resultado seria a diminuição do número de mortes, o que está bem longe de contrariar as exigências do ius naturale.

$\mathrm{Na}$ época de Vitoria, quando os mestres explicavam o ius gentium nas Sentenças de Pedro Lombardo ou na Suma Teológica, um dos exemplos mais populares era o relativo à propriedade, que inclusive fora empregado pelo próprio Aquinate em sua exposição. Como já se viu ${ }^{88}$, o teólogo burgalês também faz uso desta ilustração ao comentar a parte correspondente da Suma. Em outra parte, especificamente no âmbito de seu longo comentário à questão 62 sobre a restituição, Francisco de Vitoria se detém com mais precisão no clássico assunto da divisão das propriedades:

Si es cierto que Dios hizo todas las cosas comunes para
todos, y el ser humano es dueño de todas las cosas por derecho
natural, ¿cómo y de dónde procede la división de las cosas?
La división de las cosas no está establecida por derecho
natural. [...] Podemos decir que la división de las cosas se
llevó a cabo a partir de un consenso virtual e interpretativo,
al ocupar cada uno su lugar y dejar otros a los demás. Tal
vez ocurrió así, no mediante un acuerdo formaly preciso, sino
por acuerdo interpretativo, de modo que algunos comenzaron
a cultivar unas tierras y los demás otras, y del uso de aquellas
cosas se derivó que ése se sintiera satisfecho con las tierras que
habia ocupado y el otro con las otras, de forma que uno no
ocupaba las tierras de su vecino. ${ }^{89}$

Desta vez ele não menciona o direito das gentes, possivelmente porque já havia explicado há pouco tempo, na altura da questão 57 , que a divisão das propriedades se contava entre seus institutos. O que importa agora é que, nesta passagem, Vitoria exprime, com bastante didática, o modo como pensa que o direito das gentes se formou: no caso da propriedade privada, através de uma série de convênios privados, cada qual entre poucos indivíduos, cuja generalização terminou por consagrar a norma como instituto universal de direito das

88 Ver seção 2 do presente estudo, supra.

89 VITORIA, Francisco de. Comentários à Secunda Secundae da Suma Teológica de Santo Tomás, q. 62 a.1. In: VITORIA, Francisco de. Relectio de Potestate Civili. Estudios sobre su Filosofía Política. Edição crítica de Jesús Cordero Pando. Col. "Corpus Hispanorum de Pace”, segunda série, vol. 15. Madri: CSIC, 2008, pag. 155. 
gentes $^{90}$. Ora, trata-se de uma evolução do direito das gentes particular ao geral. Quando o mestre salmantino diz que não houve um acordo formal e preciso, mostra como, no início, grande parte do direito das gentes era fruto da mera convivência entre poucos indivíduos ou povos diferentes. As grandes regras gerais foram se plasmando lentamente na consciência das pessoas, à medida em que suas relações se sofisticavam. Não se deve esquecer, porém, como foi anteriormente exposto, que tal desenvolvimento só foi possível graças às poucas exigências do ius gentium que não se modificam, aquelas que contém um grau muito elevado de direito natural. Não houvesse este substrato de direito humano comum, os povos dificilmente se poriam de acordo, seja de modo formal, virtual ou interpretativo.

A história da instituição da propriedade privada, como contada por Vitoria, é assim um eloquente testemunho de sua divisão do direito das gentes em geral e particular, nada obstando que o segundo evolua, graças a sua aceitação universal, para a forma primária.

Passa-se agora à mais célebre das conferências vitorianas, a Relectio de Indis Recenter Inventis ou De Indis Prior, na qual examina o delicado problema da conquista espanhola da América. Vale a pena deter-se no primeiro dos títulos legítimos enunciados por Francisco de Vitoria como boas razões para a presença ibérica no Novo Mundo: o dominicano enuncia "a sociedade e comunicação natural”, complementando-o com algumas teses. A primeira é que "los españoles tienen derecho a emigrar a aquellos territorios y a permanecer alli, a condición de que no causen daño a los indios, y éstos no pueden probibirselo" ${ }^{\text {. Para }}$ provar tal proposição, amontoa nada menos que catorze argumentos, dentre os quais o seguinte: "En undécimo lugar, ellos admiten a otros indios de cualquier parte que sean. Luego harían una injusticia no admitiendo a los cristianos." 92 Não é necessário, para os propósitos do presente trabalho, questionar a veracidade desta afirmação tão genérica segundo a qual os índios seriam extremamente hospitaleiros com os nativos de outras tribos. Suponha-se,

90 Ao menos na visão de Vitoria. Hoje, pelo contrário, já é bem sabido que no século XVI numerosos povos só faziam uso rudimentar da propriedade privada. Poder-se-ia talvez argumentar que alguma forma de propriedade privada, ainda que despida das formalidades encontradas na Europa, realmente seria universal.

91 VITORIA, Francisco de. Relectio de Indis. Carta Magna de los Indios. Trad. C. Baciero, org. Luciano Pereña. Col. "Corpus Hispanorum de Pace”. Madri: CSIC, 1989., pag. 99. Em itálico no original.

92 Idem, pag. 100. como o faz Vitoria, que entre os americanos realmente houvesse tal costume de receber bem aos forasteiros. A conclusão que ele extrai é que os espanhóis não poderiam ser excluídos desta hospitalidade indígena. Note-se que aqui, ao contrário do que ocorre nas demais provas, o palestrante raciocina por indução. $\mathrm{O}$ fato de os índios praticarem a hospitalidade entre si demonstra que eles aceitaram um princípio geral de acolher os estrangeiros. Quando surgem os espanhóis e caso estes sejam repelidos, terão sido relegados a uma situação desigual e inferior em relação aos demais povos que há na América. Uma vez que a justiça exige a igualdade, os nativos não podem tratar os europeus de modo inferior ao que eles mesmos estabeleceram como padrão mínimo de conduta para com estrangeiros.

Notável neste raciocínio é o aparecimento e a eficácia do ius gentium particular. A princípio, nada parece obrigar os índios à hospitalidade. Mas depois que eles, livremente, passaram a praticá-la entre as diversas tribos, acabaram vinculados por este costume. Percebe-se mais uma aplicação do "acordo virtual ou interpretativo" que o mestre salmantino especulara como origem da propriedade privada.

A mesma construção reaparece pouco à frente, na mesma Relectio: "Si entre los indios hay bienes comunes tanto a nacionales cuanto a forasteros, no es licito a los indios probibir a los españoles la comunicación y participación de esos bienes." 93

Francisco de Vitoria podia não saber muito sobre os habitantes do Novo Mundo, mas dava grande valor a suas tradições (desde que não se opusessem ao direito natural). Caso alguma tribo permitisse algumas liberdades a membros de outras nações, os espanhóis fariam jus ao mesmo direito. Novamente, o ius gentium particular, oriundo dos contratos entre povos determinados, surge com grande força, obrigando os nativos a seguir as práticas que eles mesmos estabeleceram, evitando assim a injustiça de tratar um povo como inferior ${ }^{94}$. O

93 Idem, pag. 102.

94 É evidente que esta construção vitoriana estava afastada da realidade americana, pois os espanhóis não poderiam honestamente ser considerados como uma simples tribo entre muitas outras. Da mesma forma, ainda que se admita em tese os direitos defendidos por Vitoria, as atrocidades sofridas por alguns povos indígenas poderiam justificar que outros, cientes disso, não quisessem manter nenhum trato com os europeus. Tudo isso, porém, é irrelevante para a pesquisa aqui empreendida, até porque parece certo que o conhecimento que Vitoria possuía dos assuntos das Índias era bastante restrito. Importa antes considerar os princípios afirmados por Vitoria deixando a outros estudos, que de resto já existem, a questão de 
mesmo se diga em relação à possibilidade de naturalização dos espanhóis em uma tribo indígena:

\begin{abstract}
Es más, parece que quien quiera domiciliarse en alguna ciudad de aquellos naturales tomando, por ejemplo, esposa o por los otros medios por los que los demás extranjeros suelen adquirir la ciudadanía, no parece que pueden probibirselo más que a otros, y por consiguiente pueden gozar de los privilegios de los ciudadanos como los demás, con tal que acepten también las cargas como los demás. ${ }^{95}$
\end{abstract}

Ao contrário do que possa parecer, o regente de Prima não defendia um direito amplo e irrestrito à aquisição da cidadania local pelos “imigrantes" espanhóis, e sim a equiparação destes aos demais estrangeiros que os índios já conheciam. Ele advogava pela faculdade de seus compatriotas de beneficiar-se das mesmas regras que, em seu entendimento, vigorava entre os vários povos das Américas. Trata-se, novamente, de um postulado igualitário, pelo qual as normas livremente estabelecidas entre as tribos indígenas em seu ius gentium particular, poderiam beneficiar outras nações que viessem a aderir a tais acordos. Note-se a exigência de que os costumes pré-existentes fossem respeitados: os peninsulares deviam adequar-se aos critérios de naturalização já vigentes entre os nativos. O ius gentium geral de Vitoria obrigaria os indígenas a tratar todas as outras nações de modo igualitário, não podendo assim excluir a priori os ibéricos da "cidadania".

A discussão sobre este primeiro título legítimo de sociabilidade e comunicação naturais engloba as passagens mais famosas e posteriormente repetidas da conferência, que são aquelas nas quais o mestre aborda diretamente o direito das gentes. Observe-se que tal menção é feita de passagem, no contexto da demonstração de suas teses práticas sobre os variados direitos dos espanhóis nas Américas. Apesar de não se tratar de um estudo específico sobre o ius gentium, ao contrário do que se viu na lição sobre a quaestio 57 da Suma, foram as frases da Relectio, e não as da Lectio, que passaram para a história do direito internacional.

Uma destas passagens imortalizadas corresponde à primeira prova da tese inicial do título do ius communicationis. Como acima transcrito, Vitoria menciona que os espanhóis possuem o direito de percorrer e estabelecer-se nas terras do Novo Mundo, sempre que não causem dano aos índios. As justificativas aduzidas começam por:

saber se foram bem aplicados na América ou não.

95 VITORIA, op. cit., pag. 103.
Se prueba, en primer lugar, por el derecho de gentes, que o es derecho natural o se deriva del derecho natural (Instituciones I 2, 1): 'Se llama derecho de gentes lo que la razón natural estableció entre todas las gentes'. En efecto, en todas las naciones se considera inhumano recibir mal a los forasteros $y$ emigrantes; y por el contrario, humano y cortés comportarse bien con los forasteiros; y no sería así, si es que obraran mal los emigrantes por viajar a naciones extranjeras. ${ }^{96}$

Observe-se a vinculação estreita entre direito natural e direito das gentes nesta passagem, muito diferente da proximidade com o direito positivo que se lia nos comentários vitorianos à Suma Teológica. Porém, esta nova perspectiva não pode conduzir à conclusão de que o direito das gentes seria uma espécie de ius naturale de alcance irrestrito. Na verdade, a fonte do direito positivo não está totalmente ausente da definição emprestada de Gaio. Vitoria não dá resposta definitiva à interrogação sobre o lugar do direito dos povos: este é de direito natural ou derivado do mesmo.

A explicação de Vitoria pode ser entendida no sentido de uma alternativa: não sendo o momento de aprofundar na definição do ius gentium, ele se limita a assinalar que este possui ligação com o direito natural, e que tal ligação poderia ser mais forte ("es derecho natural") ou menos ("o se deriva del derecho natural"). A mesma lógica parece estar por trás da sequência do trecho: após estabelecer a relação entre os dois direitos, Vitoria a justifica com a citação de Gaio, que indicaria o caráter universal do ius gentium, e também com o costume universal de

96 VITORIA, op. cit., pag. 99. Sobre este trecho, há uma célebre polêmica a respeito da citação vitoriana do jurisconsulto Gaio nas Institutas. Onde o romano escrevera "quod vero naturalis ratio inter omnes homines constituit, id apud omnes populos peraeque custoditur vocaturque ius gentium", Vitoria cita "quod naturalis ratio inter omnes gentes constituit, vocatur ius gentium" (Edições históricas de Lyon e Salamanca, reimpressas em: VITORIA, Francisco de. Relecciones Teológicas del Maestro Fray Francisco de Vitoria, vol. 1. Org. L.G. Alonso Getino. Madri: Imprenta de la Rafa, 1933, pags. 382-383). Discutese o significado desta alteração de "bomines" por "gentes". A posição tradicional, defendida originalmente por Ernest Nys (NYS, Ernest. Introdução. In: VITORIA, Francisco de. De indis et de iure belli relectiones. Org. Ernest Nys. Washington, D.C.: Carnegie Institution, 1917, pags. 42-43) e aceita, entre outros, por Urdanoz (op. cit., pag. 568), entende que tal alteração foi proposital, pois Vitoria tencionava desenvolver um direito propriamente internacional a partir das regras romanas, que se aplicavam a relações interpessoais, trazendo os Estados para o centro do direito internacional. A tese oposta pode ser encontrada em Haggenmacher (op. cit., pags. 58-60), para quem a alteração deveu-se ao hábito vitoriano de citar as passagens de memória, sem conferir a isto nenhum significado especial. Também Thumfart salienta que tal alteração não passa de uma variação insignificante do texto de Gaio, pois o ius gentium vitoriano não põe o Estado em primeiro plano, e sim o indivíduo (THUMFART, op. cit., pag. 244). 
receber bem os viajantes, de caráter mais positivo.

A duplicidade fica mais clara quando o teólogo trata de fundamentar outra proposição:

\begin{abstract}
Si entre los indios hay bienes comunes tanto a nacionales como a forasteros, no es lícito a los indios probibir a los españoles la comunicación y participación de esos bienes.

$[\cdots]$

En este tema son muchos los puntos que parecen derivar del derecho de gentes. Obsérvese que si el derecho de gentes tiene en buena parte su origen en el derecho natural, claramente tiene fuerza para conceder derechos y crear obligaciones. Y en el supuesto de que no siempre tenga su origen en el derecho natural, si parece que se tienen en cuenta el consentimiento de la mayor parte del orbe, sobre todo cuando se trata del bien común de todos. Porque si desde los primeros tiempos de la creación del mundo y de su reconstrucción después del diluvio la mayoría de los hombres estableció que los embajadores en todas partes fueran inviolables, que los mares fueran comunes, que los prisioneros de guerra fueran esclavos, y que asimismo convenia que los extranjeros no fueran expulsados, ciertamente esto tendría fuerza de ley, aun con oposición de los demás. ${ }^{97}$
\end{abstract}

Outra vez, o mestre salmantino prioriza o aspecto prático em detrimento de esclarecer definitivamente a proveniência do direito das gentes. Como se lê, ele está interessado em defender a obrigatoriedade das normas de ius gentium. Para desincumbir-se eficazmente desta tarefa, desenvolve estratégias de persuasão tanto para os que alinhavam o ius gentium ao ius naturale quanto para os que preferiam admiti-lo entre o direito civil. Conclui, assim, que nos dois casos, os diversos povos estarão vinculados pelo direito das gentes. A única distinção é que, quando se tratar de um direito consentido (ius gentium no segundo sentido, ou particular), a norma só atingirá as nações que a ela aderirem, podendo inclusive prevalecer sobre um comando de ius gentium primário, ou universal, em sentido contrário. Parece evidente que a menção à escravização dos prisioneiros de guerra foi feita por Vitoria pensando no contexto dos possíveis confrontos entre espanhóis e indígenas - mas ele devia estar bem consciente da existência do preceito específico do ius gentium que derrogara tal disposição quando a luta fosse entre cristãos.

Portanto, os dois trechos mais "teóricos" da Relectio de Indis Prior sobre o direito das gentes caracterizam-se por sua ambiguidade no tocante à real natureza deste último. O conferencista evita tomar partido decididamen-

97 VITORIA, Francisco de. Relectio de Indis. Carta Magna de los Indios. Trad. C. Baciero, org. Luciano Pereña. Col. "Corpus Hispanorum de Pace". Madri: CSIC, 1989, pag. 102. te por um dos lados, preferindo mostrar como as duas posições rivais coincidiriam em apoio de suas teses concretas (direitos subjetivos ao ingresso e permanência em outro país, direito de adquirir a cidadania estrangeira e de ser tratado como igual, direito de participar na fruição dos bens comuns etc. $)^{98}$. Importante sublinhar que os parágrafos acima transcritos não fecham a porta à possibilidade de que o "consentimento do orbe" ocorra em pequena escala, entre poucas nações. Afinal, o direito que vale "entre todas as gentes" pode ser visto como apenas uma das duas formas possíveis de ius gentium.

Prosseguindo na conferência sobre os índios, encontra-se uma importante aplicação do direito das gentes particular na admissão do título do auxílio aos aliados como causa para guerra justa. Citando o exemplo dos tlaxcalas, que se uniram aos soldados de Cortez contra os astecas, Vitoria destaca que "la defensa de los aliados y amigos es causa justa de guerra" "Neste caso, o ataque armado decorrerá de uma norma específica de direito das gentes estabelecida pela aliança entre as duas nações, que ampliará, neste ponto específico, o preceito do ius gentium universal segundo o qual a força somente pode ser empregada em defesa de um direito ou resposta a uma injúria recebida ${ }^{100}$. Note-se que a defesa dos amigos manu militari não se confunde com a reparação de um dano sofrido pela república. Trata-se de uma conduta cuja justificativa reside no direito alheio que foi violado. Segundo Vitoria, a guerra em legítima defesa de terceiro seria lícita em dois casos: quando o príncipe estivesse agindo para garantir a paz e a justiça no orbe ${ }^{101}$, ou quando estivesse vinculado a algum pacto

98 "Quando Vitória se preocupa com o fundamento de validade [do direito das gentes], este decorre da natureza; quando ele considera a questão de somenos importância, a origem é de direito positivo." MACEDO, op. cit., pag. 11. Disponível em: < https://www. publicacoesacademicas.uniceub.br/rdi/article/view/1602/1591 >. Acesso em: 10.07.2017.

99 VITORIA, op. cit., pag. 110.

100 Francisco de Vitoria já se havia pronunciado a favor da guerra em defesa de aliados ao comentar a questão 40 (De Bello) da II-II da Suma Teológica. Ver VITORIA, Francisco de. Quaestio de Bello. In: VITORIA, Francisco de. Relectio de Iure Belli o Paz Dinámica. Org. Luciano Pereña. Col. "Corpus Hispanorum de Pacis", vol. 6. Madri: CSIC, 1981, pag. 219.

101 Por exemplo, quando um príncipe resolvesse tomar a defesa de um povo que estivesse sendo vítima de tirania e truculência por parte de seu governante. Interessante notar que Vitoria primeiro afirma este direito na teoria ("en general, cuando los súbditos tienen derecho a luchar contra su rey, pueden los príncipes luchar a favor del pueblo. La razón está en que el pueblo es inocente y los príncipes pueden y les es lícito por derecho natural defender el orbe para que no se le haga injusticia" Idem, pags. 219221), para depois leva-lo à prática, ao admitir a defesa dos nativos 
que lhe impusesse a defesa de outra república que estivesse ameaçada. A diferença entre estas duas situações residiria em que, no primeiro caso, a obrigatoriedade da ação seria sensivelmente menor que no segundo. Além disso, o primeiro motivo, mais importante, restringirá o segundo, de modo que não será permitido vir em auxílio de algum aliado caso seja evidente que este não possui razão na disputa ${ }^{102}$.

Porém, o direito das gentes particular também pode ser invalidado caso seu teor viole o direito natural. É o que se vê quando Vitoria denunciava o título ilegítimo da "eleição voluntária", alegado pelos espanhóis quando conseguiam fazer com que alguma nação índia consentisse com o domínio dos Reis Católicos. O que, à primeira vista, poderia parecer um simples pacto entre dois povos, apto a criar novas normas de direito das gentes que regulassem o convívio entre ambos, é descartado pelo mestre salmantino em virtude do vício de consentimento que encontra em tais acordos:

\footnotetext{
En primer lugar, no deberían intervenir el miedo y la ignorancia, que vician toda elección. Ahora bien, ambos factores intervienen en aquellas elecciones y aceptaciones; pues los indios no saben lo que hacen, y aún quirá ni entienden lo que les piden los españoles. Además se lo piden a una turba inerme y medrosa, a la que rodean con las armas en la mano. ${ }^{103}$
}

Embora o raciocínio de Vitoria seja fácil de entender e apoiar, ele parece encontrar-se em contradição com a solução dada por ele a outro problema envolvendo coação na conclusão de um tratado. Após a batalha de Pavia (1525), o rei francês Francisco I fora capturado pelo Imperador Carlos $\mathrm{V}$ e conduzido a Madri, onde passara algum tempo em cativeiro. Para obter sua liber-

americanos que estivessem sofrendo injustiças reiteradas por parte de seus líderes como uma das causas para a guerra justa dos espanhóis nas Américas ("Otro título podría ser la tiranía de los mismos caciques de los indios o sus leyes tiránicas en daño de los inocentes, el sacrifício, por ejemplo, de hombres inocentes o la matanza, otras veces, de hombres libres de culpa con el fin de comer su carne" - VITORIA, Francisco de. Relectio de Indis. Carta Magna de los Indios. Trad. C. Baciero, org. Luciano Pereña. Col. "Corpus Hispanorum de Pace". Madri: CSIC, 1989, pag. 109). 102 Ao discutir a delicada situação do ducado de Milão, objeto de discórdia entre Carlos V e Francisco I, Vitoria afirma que os espanhóis poderiam auxiliar o milanês (cuja política era pró ibérica) a pedido deste caso ficasse estabelecido que ele governava o ducado com justo título. VITORIA, Francisco de. Relectio de Iure Belli o Paz Dinámica. Org. Luciano Pereña. Col. "Corpus Hispanorum de Pacis”, vol. 6. Madri: CSIC, 1981, pag. 225.

103 VITORIA, Francisco de. Relectio de Indis. Carta Magna de los Indios. Trad. C. Baciero, org. Luciano Pereña. Col. "Corpus Hispanorum de Pace". Madri: CSIC, 1989, pag. 96. dade, precisou assinar um tratado ${ }^{104}$, naturalmente bastante desfavorável a seu país. Assim que cruzou os Pirineus, porém, o rei gálico recusou-se a cumprir diversos pontos do pacto, argumentando que tal convenção era nula por haver sido assinada sob coação.

Em sua lição sobre a Quaestio de Bello de Santo Tomás, Vitoria rejeita esta razão oferecida pelo rei francês afirmando que, ainda que o tratado fosse desvantajoso e só obtido devido a seu estado de prisioneiro, o rei Francisco permanecia vinculado ao mesmo, para que a violação do pactuado não conduzisse a uma perpetuação das guerras ${ }^{105}$.

Esta censura formulada contra o rei Francisco I faz surgir uma aparente contradição no raciocínio vitoriano. O regente de Prima não aceitara as razões do monarca para liberar-se das obrigações do tratado de Madri. Já no caso dos índios e dos conquistadores, denuncia os acordos como nulos. O que aconteceu?

Parece que o teólogo dominicano não considerou que tais situações fossem semelhantes. E, realmente, há que se tomar em conta que Francisco I e Carlos V estavam em pé de igualdade no que tange à compreensão do que faziam quando celebravam o tratado. Por mais que o soberano gálico estivesse sendo forçado por sua prisão a concordar com termos desagradáveis, ele não recebia tratamento pior do que o de outros príncipes europeus cativos na época. Ao comentar seu caso, Vitoria ainda teve o cuidado de ressaltar que o tratado "forçado" não poderia ser excessivo em suas concessões, nem aproveitar-se da desventura do soberano para ameaçar a sobrevivência da França ${ }^{106}$. Dentro destes amplos limites, porém, o teólogo não acredita que o rei francês poderia alegar coação contra o pacto que ele se dispusera a assinar.

Os nativos americanos, por sua vez, sequer sabiam o que estava em jogo quando ouviam os espanhóis proclamar seus "direitos" às terras e convidá-los a uma submissão pacífica. Com efeito, sabe-se que a estratégia de aproximação predileta dos castelhanos consistia em uma proclamação unilateral, o Requerimiento, que, após uma brevíssima síntese da religião cristã e dos poderes do Papa e do Imperador (muitas vezes lido em latim),

104 Tratado de Madri de 1526.

105 VITORIA, Francisco de. Relectio de Iure Belli o Paz

Dinámica. Org. Luciano Pereña. Col. "Corpus Hispanorum de Pacis”, vol. 6. Madri: CSIC, 1981, pags. 259-261.

106 Idem, pag. 259. 
incitava os índios a uma pronta vassalagem a tais senhores, sem que os nativos jamais os tivessem visto ou tido qualquer notícia daqueles ${ }^{107}$.

Assim, no primeiro caso, a coação seria derivada da derrota em batalha; no segundo, da ignorância. Vitoria segue raciocínios distintos nas duas situações, os quais refletem os dois tipos de ius gentium estudados nestas páginas. O caso do rei Francisco é remetido ao direito das gentes particular: havendo um pacto entre duas nações, este deve ser obedecido ${ }^{108}$. Os acordos hispano-indígenas são analisados pelo direito das gentes geral: medo e ignorância viciam toda e qualquer eleição, nas palavras de Vitoria.

A comparação entre as duas espécies de acordos envolvendo a Espanha evidencia a duplicidade do direito das gentes na concepção do mestre salmantino. Parece certo que, para ele, o ius gentium particular, por operar em um ambiente mais restrito e depender do consentimento expresso dos envolvidos, é mais exigente em relação à igualdade dos participantes. Já o ius gentium público aplica-se sempre que mais de um povo estiver presente, não importando as diferenças de cultura ou nível tecnológico que existam entre eles.

Esta tese vitoriana não passou despercebida por seus primeiros sucessores. Domingo de Soto, por exemplo, que frequentemente substituía Vitoria em sua cátedra de Prima durante as doenças do burgalês, também se deu conta do caráter dúplice do ius gentium. Em seu comentário ao artigo $3^{\circ}$ da quaestio 57 do Tratado da Justiça de Santo Tomás, de Soto não tem dúvidas em situar o direito das gentes como uma espécie do direito positivo, afirmando às claras aquilo que era somente insinuado em Vitoria:

El derecho de gentes distínguese del derecho natural y se comprende bajo el derecho positivo. ${ }^{109}$

107 Em um interessante estudo sobre o Requerimiento, Patricia Seed conclui que o mesmo reproduzia a lógica unilateral que os espanhóis haviam tomado dos contatos oficiais do Islã, quando este era a religião dominante na Península Ibérica, com os cristãos. SEED, Patricia. Cerimônias de posse na conquista européia do Novo Mundo (1492-1640). São Paulo: UNESP, 1999, pags. 101-141.

108 Também a hipótese de que o vencedor exija um tratado extorsivo é abordada por Vitoria segundo a lógica do direito das gentes particular: "Si se causase un daño gravísimo a la patria hasta el punto de desaparición, entonces no babría que cumplir la palabra dada, pues en un caso asi tampoco nosotros podriamos pedir en justicia que se cumpliese la palabra dada." O raciocínio de reciprocidade é típico da lógica "horizontal" do direito das gentes secundário ou particular em Francisco de Vitoria. VITORIA, op. cit., pag. 259.

109 DE SOTO, Domingo. Tratado de la justicia y el derecho,
El derecho natural es absolutamente necesario, es decir, que no depende del humano consentimiento; mas, el derecho de gentes obliga porque parece así, es decir, porque es juzgado así por los hombres; y nunca se dividirían las posesiones de las cosas, si no consintieren los hombres, en que unos poseyeran aquéllas y otros las otras; luego, el derecho de gentes no es absolutamente natural, sino positivo. ${ }^{110}$

A seguir, o confessor de Carlos V se ocupa de distinguir entre o direito das gentes necessário e aquele que pode ser "dispensado com causa" 111 . Ele exemplifica o primeiro com a divisão das coisas (embora admita, na mesma frase, que na vida religiosa possa não ocorrer tal apropriação privada). Já a servidão, alguns contratos civis e certas obrigações em tempo de guerra podem ser excepcionados havendo causa suficiente:

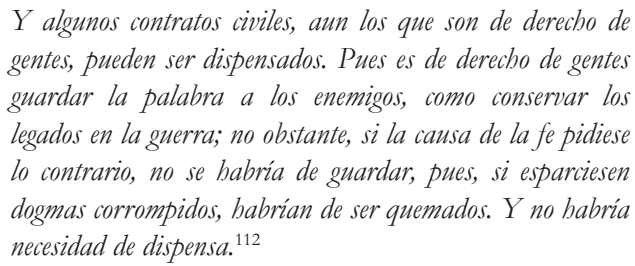

É verdade que a argumentação de Soto não é muito elaborada ${ }^{113}$. Contudo, importante notar que ele segue Vitoria na distinção entre um direito das gentes geral, que obriga a todos por igual, e um específico, que pode eventualmente ser derrogado em favor de uma relação justa.

Apesar de não dizê-lo com estas palavras, os exemplos que de Soto utiliza evidenciam que a dispensa do direito das gentes restrito obedeceria a uma exigência do direito natural. Isto é um pouco diferente do raciocínio vitoriano, no qual a simples falta de consentimento impediria a eficácia de normas de ius gentium específico ou secundário. O burgalês parece conferir maior peso à liberdade das nações de autogerir seus negócios exteriores do que seu sucessor em Salamanca. Seja como for, a divisão no seio do direito das gentes é clara em de Soto, confirmando sua existência em Vitoria ${ }^{114}$.

tomo II. Trad. espanhola de Jaime Torrubiano Ripoll. Madri: Editorial Reus, 1926, pag. 203.

110 Idem, pag. 205.

111 Idem, pag. 209.

112 Idem, ibidem

113 SILVA, Paula Oliveira e; CALVÁRIO, Patrícia. A fundamentação, natural ou positiva, do direito das gentes em alguns comentários seiscentistas à Suma de Teologia de Tomás de Aquino II-IIae, q. 57, a.3. In: Revista Aquinate, ${ }^{\circ} 14$ (2011), pags. 41-42.

114 Em curso ministrado na Academia de Direito Internacional de Haia sobre o fundamento do Direito Internacional em perspectiva histórica, Alfred Verdross nota que Francisco Suárez, em certa perspectiva um continuador de Vitoria nas investigações sobre o 


\section{Conclusão}

Francisco de Vitoria concorda com Tomás de Aquino em que o direito das gentes é a primeira concretização do direito natural. Trata-se do local de manifestação inicial da vontade humana, cujo âmbito de atuação ainda é bastante restrito em comparação com as exigências obrigatórias que emanam do ius naturale. Na grande divisão do direito que define o jusnaturalismo clássico, entre direito natural e positivo, o ius gentium ocupa um plano intermediário, porém mais próximo deste último. A interferência da vontade humana é apontada por Vitoria como decisiva para afastar definitivamente o direito das gentes do justo por natureza.

Esta vontade humana, porém, pode manifestar-se de duas maneiras diferentes. Pode reconhecer a essencialidade de certas condutas diante de um cenário histórico amplo, limitando-se a externalizar e promover uma ação por considerá-la justa necessariamente. Neste caso, estar-se-á perante o ius gentium público ou geral, que obriga todos os povos por corresponder a traços universalmente repetidos da natureza humana. Este direito dos povos se beneficiará de uma aceitação quase universal, pois corresponde a circunstâncias genéricas que podem ser encontradas na vida de todas as nações.

A segunda maneira de a vontade operar na definição do ius gentium é através do livre acordo entre as nações, pelo qual direitos e obrigações mútuos são fixados e em virtude do qual, indiretamente, se contribui para a paz entre os povos. Nesta segunda situação, o arbítrio humano aparece com maior destaque, podendo escolher entre os vários possíveis pactuantes e objetos do contrato. O ius gentium particular faz jus a seu nome por impor deveres e atribuir direitos aos indivíduos tomados

direito das gentes, também menciona duas espécies deste direito, consistindo a primeira no direito que as nações observam entre si, e a segunda no direito interno comum a todas elas. Embora a descrição destas espécies divirja da vitoriana aqui estudada, é de dizer-se que a incompatibilidade não é total: o primeiro ius gentium de Suárez aproxima-se do segundo de Vitoria, enquanto que o outro, formado a partir de uma igualdade de condutas internas, pode muito bem ser consequência da adoção do ius gentium vitoriano primário. Ver: VERDROSS, Alfred. O fundamento do direito internacional. Revista de Direito Internacional, Brasília, v. 10, n. 2, 2013, pag. 2. Título original: Le fondement du droit international. Recueil des cours de l'Académie de Droit International, 1927, p. 325-384. Tradução de Marcelo Dias Varella (coordenador), Amábile Pierroti, Luiza Nogueira e Marlon Tomazette. Disponível em: < https:// www.publicacoesacademicas.uniceub.br/rdi/article/view/2685/ pdf $>$. Acesso em: 10.07.2017. enquanto comunidade.

$\mathrm{O}$ que une as duas vertentes do direito das gentes é sua função de trazer paz às relações entre as comunidades, possibilitando o diálogo jurídico entre nações distintas, iguais em soberania e com leis e costumes dissonantes entre si. O ius gentium específico depende do genérico, pois a vontade dos contratantes não está livre para violar o direito natural. Portanto, nem tudo pode ser objeto de um tratado. Por outro lado, a exigência específica do direito natural pode ser difícil de enxergar diante de um caso concreto, tornando necessária a intervenção do ius gentium primário, adequado a todos os povos, para materializar o direito natural.

Formado por estes dois componentes, o ius gentium distingue-se do direito natural por sua dependência das circunstâncias concretas nas quais se dá a relação jurídica. O direito natural determina o que é justo considerando apenas o postulado genérico da igualdade. Já o direito das gentes também leva em conta os fatores históricos, sociais, econômicos etc. que influem na relação jurídica determinada e a concretizam.

$\mathrm{Na}$ verdade, a relação entre estes dois ramos do direito dos povos espelha a relação existente entre direito natural e positivo. Tal como o direito positivo é necessário para conferir aplicabilidade ao direito natural, assim também o direito das gentes consensual ou pactuado é necessário para indicar concretamente o que é devido a qual comunidade. E, da mesma maneira que o direito natural constitui um guia seguro para o direito positivo, impedindo excessos que poderiam redundar em injustiça, o direito das gentes geral representa um limite perante o qual a liberdade dos contratantes cessa.

De todo o exposto, algumas conclusões saltam à vista:

Em primeiro lugar, observou-se que a dialética "direito natural - direito positivo" não se refere somente aos primeiros fundamentos do fenômeno jurídico, mas pode ser encontrada também em outros ramos do direito. Como evidenciado por Francisco de Vitoria, o sistema do direito das gentes exibe uma parte com maior proximidade com o direito natural e outra mais próxima do direito positivo. O objeto deste estudo foi apenas o ius gentium, e tão somente na parte em que Vitoria o analisou, mas é possível aventar que a mesma dialética se faça presente igualmente em outros ramos do direito. Direito natural e positivo não são divisões didáticas entre as várias normas, mas espécies de fontes do direito, 
que indicam para onde se deve olhar na busca por regras que disciplinem uma certa disputa.

Em segundo lugar, nota-se que a distinção proposta pelo mestre salmantino de modo um tanto descuidado, enquanto buscava provar outros pontos, acabou por constituir um dos traços mais dinâmicos e permanentes de sua concepção de ius gentium. Com efeito, seu esquema de raciocínio pode ser aplicado sem muitas adaptações ao direito internacional público dos tempos atuais. A sociedade internacional do século XXI também se organiza separando dois tipos de direito internacional. Da mesma forma que evidenciado por Vitoria, existe o entendimento de que algumas normas internacionais são universais e obrigatórias, enquanto que outras são particulares e suscetíveis de derrogação.

O conceito contemporâneo de ius cogens insere-se na primeira definição. Trata-se da parte do direito internacional que é insuscetível de derrogação pelo direito positivo, devido ao fato de constituir pressuposto necessário para a manutenção do restante da ordem jurídica internacional. Embora a existência desta figura jurídica não possa ser negada, ex vi dos arts. 53 e 64 da Convenção de Viena sobre o Direito dos Tratados ${ }^{115}$, a determinação de seu conteúdo está longe de ser pacífica ${ }^{116}$. Seja

115 "Artigo 53. É nulo um tratado que, no momento de sua conclusão, conflite com uma norma imperativa de Direito Internacional geral. Para os fins da presente Convenção, uma norma imperativa de Direito Internacional geral é uma norma aceita e reconhecida pela comunidade internacional dos Estados como um todo, como norma da qual nenhuma derrogação é permitida e que só pode ser modificada por norma ulterior de Direito Internacional geral da mesma natureza." "Artigo 64. Se sobrevier uma nova norma imperativa de Direito Internacional geral, qualquer tratado existente que estiver em conflito com essa norma torna-se nulo e extingue-se." Também o Projeto de Artigos da Comissão de Direito Internacional das Nações Unidas faz referência ao ius cogens em seus artigos 40 e 41, que compõem o capítulo intitulado "Violações graves de obrigações decorrentes de normas imperativas de direito internacional geral".

116 Autores como Jean Combacau e Serge Sur consideram que tal conteúdo é inalcançável (COMBACAU, Jean e SUR, Serge. Droit international public, $7^{\mathrm{a}}$ ed. Paris: Montchrestien, 2006, pags. 5253). Stephan Hobe sustenta que o ius cogens é formado hoje pela vedação do uso da força e respeito aos direitos humanos mais bási$\cos$ (HOBE, Stephan. Einführung in das Völkerrecht, 9 $9^{a}$ ed. Tübingen: Francke, 2008, pag. 180), enquanto André de Carvalho Ramos acrescenta a autodeterminação dos povos (RAMOS, André de Carvalho. Comentários ao artigo 53. In: SALIBA, Aziz Tuffi. Direito dos Tratados. Comentários à Convenção de Viena sobre o Direito dos Tratados (1969). Belo Horizonte: Arraes, 2011, pags. 458-466). Já Celso Mello inclui a Carta da ONU na categoria de norma de ius cogens (MELLO, Celso R.D.A. Curso de Direito Internacional Público, vol. I, $15^{\mathrm{a}}$ ed. Rio de Janeiro: Renovar, 2004, pag. 217). Valério Mazzuoli propõe o costume internacional geral, os tratados multilaterais sobre temas essenciais e as normas que consa- como for, a discussão deixa claro que o voluntarismo dos sujeitos do direito internacional não abrange todas as matérias. Embora alguns autores afirmem que o ius cogens depende da vontade dos Estados em atribuir-lhe certas normas de direito internacional ${ }^{117}$, a verdade é que há um consenso em que somente as regras que expressem valores centrais da comunidade internacional possam receber tal qualificação.

O conceito do ius cogens parece corresponder ao ius gentium público de Francisco de Vitoria. Em ambos observa-se a generalidade, a inderrogabilidade e a essencialidade. E é importante considerar que o ius cogens é um instituto de vida recente, surgido no decorrer do século XX para salvaguardar os pilares do direito internacional. Isso corresponde a outra característica do ius gentium geral, que é a sua dependência da vontade positiva. Embora seja um direito necessário e universalmente válido, ele, diferentemente do direito natural, depende de manifestações específicas de vontade para adquirir forma. O mesmo ocorre com o direito internacional necessário: este reflete valores atemporais, como o respeito pela sacralidade da vida humana, pela propriedade, pela forma de vida dos grupos humanos etc. $\mathrm{Na}$ figura do ius cogens, tais valores universais são concretizados na linguagem específica da época contemporânea, na forma de direitos subjetivos, positivados, de aplicação fiscalizada por órgãos internacionais etc. É neste modo de expressão dos valores universais que o ius cogens pode dizer-se produto de um acordo entre todos os povos do mundo.

Também o outro lado do direito das gentes vitoriano, o direito particular ou específico, aproxima-se da figura hodierna do direito internacional positivo com sua ênfase na igualdade dos sujeitos e no consenso na produção das regras.

Nesta perspectiva, o grande aporte de Francisco de Vitoria é a ligação umbilical que se nota entre as duas espécies de ius gentium. Embora uma se vincule mais ao direito natural e a outra, ao direito positivo, é evidente

gram garantias fundamentais do ser humano (MAZZUOLI, Valério de Oliveira. Curso de Direito Internacional Público, $5^{a}$ ed. São Paulo: Revista dos Tribunais, 2011, pag. 155).

117 SHAW, Malcolm N. International Law, 6a ed. Nova York: Cambridge University Press, pags. 126-127: “The appropriate test would thus require universal acceptance of the proposition as a legal rule by states and recognition of it as a rule of jus cogens by an overwhelming majority of states, crossing ideological and political divides. It is also clear that only rules based on custom or treaties may form the foundation of jus cogens norms." 
que, para ele, se tratam de duas componentes do mesmo ordenamento jurídico, destinadas a produzir efeitos e indicar o justo nas mesmas relações jurídicas. Pode-se inclusive aventar que é por causa desta ligação essencial que a distinção entre o direito das gentes geral e específico não é explicitamente mencionada por Vitoria, havendo necessidade de perquirir seus textos sobre o assunto para perceber a existência desta separação, como foi feito na seção anterior deste texto.

Porém, a dualidade existe, e demonstra como o direito natural possui influência sobre o direito das gentes vitoriano. Para o mestre salmantino, o ius naturale, centrado na exigência básica de igualdade entre os indivíduos participantes de uma relação jurídica, constituía o fundamento e o norte do direito das gentes. Desta forma, o ius gentium particular ou específico, decorrente da vontade das nações expressa em acordos, não é desprovido de uma finalidade última. Embora seu conteúdo possa variar indefinidamente de acordo com as circunstâncias de tempo, espaço e interesses de seus criadores, ele se encontra umbilicalmente vinculado ao ius gentium geral, e deve especificar e concretizar os termos do grande acordo tácito entre as nações que constitui o direito das gentes em sentido amplo. Em outras palavras, Vitoria estabelece uma razão de ser para o direito internacional: este existe para manter a paz entre as repúblicas garantindo que cada indivíduo em seu interior receba o que lhe cabe.

\section{REFERÊNCIAS}

AA.VV. Digesto de Justiniano. Liber Primus. Introdução ao Direito Romano. Tradução de Hélcio Maciel França Madeira. $3^{a}$ ed. São Paulo: Revista dos Tribunais. Osasco: UNIFIEO, 2002

AQUINO, Santo Tomás de. Suma de Teología, vol. 2, $2^{a}$ ed. Madri: BAC, 1989

AQUINO, Santo Tomás de. Suma de Teología, vol. 3. Madri: BAC, 1990

ARISTÓTELES, Ética a Nicômaco. Tradução de António de Castro Caeiro. São Paulo: Atlas, 2009

AZEVEDO, Luiz Henrique Cascelli de. Ius Gentium em Francisco de Vitoria: a fundamentação dos Direitos Humanos e do Direito Internacional na tradição tomista. Porto Alegre: Sergio Antonio Fabris, 2008
BASTOS JUNIOR, Luiz Magno Pinto. Rever ou romper com Vestfália? Por uma releitura da efetiva contribuição dos acordos de paz de 1648 à construção do modelo vestfaliano de Estados. Revista de Direito Internacional, Brasília, v. 14, n. 1, 2017, pags. 357-376, esp. pag. 363. Disponível em: < https://www.publicacoesacademicas.uniceub.br/ $/ \mathrm{rdi} /$ article/view $/ 4397>$. Acesso em: 10.07.2017

COMBACAU, Jean e SUR, Serge. Droit international public, $7^{\mathrm{a}}$ ed. Paris: Montchrestien, 2006

CRUZ CRUZ, Juan. La soportable fragilidad de la ley natural: consignación transitiva del ius gentium en Vitoria. In: CRUZ CRUZ, Juan: Ley y dominio en Francisco de Vitoria. Pamplona: EUNSA, 2008

DE SOTO, Domingo. Tratado de la justicia y el derecho, tomo II. Trad. espanhola de Jaime Torrubiano Ripoll. Madri: Editorial Reus, 1926

FAZIO FERNANDEZ, Mariano. Francisco de Vitoria: cristianismo y modernidad. Buenos Aires: Ciudad Argentina, 1998

FAZIO, Mariano e MERCADO CEPEDA, Pedro. Las dimensiones política y jurídica del totus orbis en Francisco de Vitoria. In: CRUZ CRUZ, Juan (org.). Ley y domínio en Francisco de Vitoria. Pamplona: EUNSA, 2008

GAIUS. Institutas do Jurisconsulto Gaio. Tradução de J. Cretella Jr. e Agnes Cretella. São Paulo: Revista dos Tribunais, 2004

HAGGENMACHER, Peter. La place de Francisco de Vitoria parmi les fondateurs du droit international. In: TRUYOL SERRA, Antonio et al. Actualité de la pensée juridique de Francisco de Vitoria. Bruxelas: Bruylant, 1988

HERRERA, Daniel Alejandro. Ius gentium: ¿derecho natural o positivo? In: IDOYA ZORROZA, María (org.). Proyecciones sistemáticas e históricas de la teoría suareciana de la ley. Col. Cuadernos de pensamento español, $\mathrm{n}^{\circ}$ 37. Pamplona: Universidad de Navarra, 2009

HOBE, Stephan. Einführung in das Völkerrecht, $9^{\mathrm{a}}$ ed. Tübingen: Francke, 2008

MACEDO, Paulo Emílio Vauthier Borges de. O mito de Francisco de Vitoria: defensor dos direitos dos índios ou patriota espanhol? Revista de Direito Internacional, Brasília, v. 9, n. 1, jan./jun. 2012, pag. 11. 
Disponível em: < https://www.publicacoesacademicas. uniceub.br/rdi/article/view/1602/1591 > . Acesso em: 10.07.2017.

MAZZUOLI, Valério de Oliveira. Curso de Direito Internacional Público, $5^{a}$ ed. São Paulo: Revista dos Tribunais, 2011

MELLO, Celso R.D.A. Curso de Direito Internacional Público, vol. I, $15^{\mathrm{a}}$ ed. Rio de Janeiro: Renovar, 2004

SALIBA, Aziz Tuffi. Direito dos Tratados. Comentários à Convenção de Viena sobre o Direito dos Tratados (1969). Belo Horizonte: Arraes, 2011

SEED, Patricia. Cerimônias de posse na conquista européia do Novo Mundo (1492-1640). São Paulo: UNESP, 1999

SHAW, Malcolm N. International Law, 6a ed. Nova York: Cambridge University Press, 2008

SILVA, Paula Oliveira e; CALVÁRIO, Patrícia. A fundamentação, natural ou positiva, do direito das gentes em alguns comentários seiscentistas à Suma de Teologia de Tomás de Aquino II-IIae, q. 57, a.3. In: Revista Aquinate, $\mathrm{n}^{\circ} 14$ (2011)

THUMFART, Johannes. Die Begründung der globalpolitischen Philosophie: Francisco de Vitorias Vorlesung über die Entdeckung Amerikas im ideengeschichtlichen Kontext. Berlim: Kulturverlag Kadmos, 2012

VERDROSS, Alfred. O fundamento do direito internacional. Revista de Direito Internacional, Brasília, v. 10, n. 2, 2013, pag. 2. Título original: Le fondement du droit international. Recueil des cours de l'Académie de Droit International, 1927, p. 325-384. Tradução de Marcelo Dias Varella (coordenador), Amábile Pierroti, Luiza Nogueira e Marlon Tomazette. Disponível em: < https://www.publicacoesacademicas.uniceub.br/rdi/ article/view/2685/pdf > . Acesso em: 10.07.2017

VILLEY, Michel. A formação do pensamento jurídico moderno. São Paulo: Martins Fontes, 2005

VILLEY, Michel. Filosofia do Direito. São Paulo: Martins Fontes, 2003
VITORIA, Francisco de. De indis et de iure belli relectiones. Ed. Ernest Nys. Washington, D.C.: Carnegie Institution, 1917

VITORIA, Francisco de. El tráfico de esclavos realizado por los portugueses. Fragmento de una carta al padre Bernardino de Vique. In: VITORIA, Francisco de. Relecciones sobre los indios y el derecho de guerra, $3^{\text {a }}$ ed. Madri: Espasa-Calpe, 1975

VITORIA, Francisco de. La justicia. Tradução e introdução de Luis Frayle Delgado. Madri: Tecnos, 2003

VITORIA, Francisco de. La ley. Tradução de Luis Frayle Delgado. $2^{\text {a }}$ ed. Madri: Tecnos, 2009

VITORIA, Francisco de. Obras de Francisco de Vitoria. Relecciones teológicas. Ed. Teófilo Urdanoz. Madri: Biblioteca de Autores Cristianos, 1960

VITORIA, Francisco de. Quaestio de Bello. In: VITORIA, Francisco de. Relectio de Iure Belli o Paz Dinámica. Org. Luciano Pereña. Col. "Corpus Hispanorum de Pacis”, vol. 6. Madri: CSIC, 1981

VITORIA, Francisco de. Relecciones Teológicas del Maestro Fray Francisco de Vitoria, vol. 1. Org. L.G. Alonso Getino. Madri: Imprenta de la Rafa, 1933

VITORIA, Francisco de. Relectio de Indis. Carta Magna de los Indios. Trad. C. Baciero, org. Luciano Pereña. Col. "Corpus Hispanorum de Pace". Madri: CSIC, 1989

VITORIA, Francisco de. Relectio de Indis o libertad de los indios. Trad. L. Pereña e J.M. Perez Prendes, Org. Luciano Pereña. Col. "Corpus Hispanorum de Pace”, vol. 5. Madri: CSIC, 1967

VITORIA, Francisco de. Relectio de Iure Belli o Paz Dinámica. Org. Luciano Pereña. Col. "Corpus Hispanorum de Pacis”, vol. 6. Madri: CSIC, 1981

VITORIA, Francisco de. Relectio de Potestate Civili. Estudios sobre su Filosofía Política. Edição crítica de Jesús Cordero Pando. Col. "Corpus Hispanorum de Pace”, segunda série, vol. 15. Madri: CSIC, 2008 
Para publicar na Revista de Direito Internacional, acesse o endereço eletrônico www.rdi.uniceub.br ou www.brazilianjournal.org.

Observe as normas de publicação, para facilitar e agilizar o trabalho de edição. 